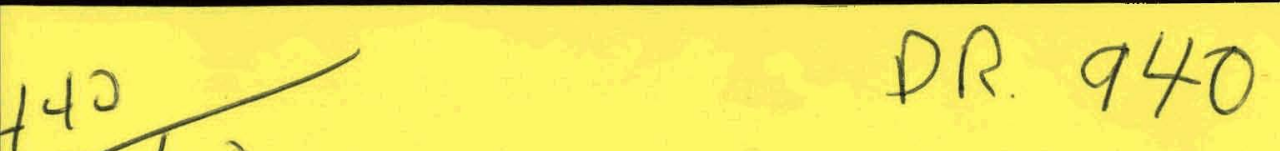

\title{
SILICON WEB PROCESS DEVELOPMENT
}

Quarterly Report, July 1-September 30, 1979

By
C. S. Duncan
R. Seidensticker
F. E. Hill
M. E. Skutch
R. H. Hopkins
J. P. McHugh
J. M. Driggers

\section{MASTER}

Work Performed Under Contract No. NAS-7-100-954654

Westinghouse Research and Development Center

Pittsburgh, Pennsylvania

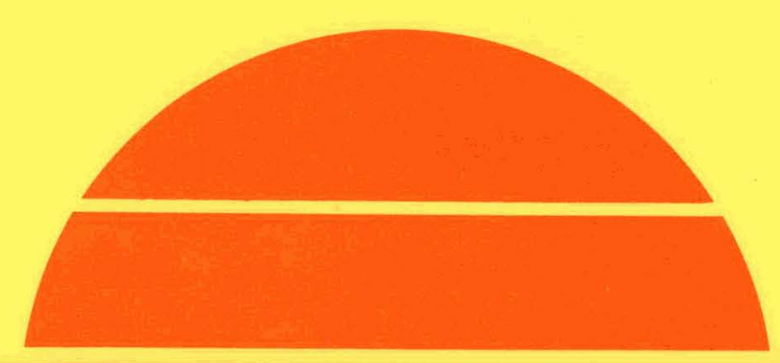

\section{U.S. Department of Energy}

DISTRIBUTION OF THIS BOCUMERT IS UNLIMTEE 


\section{DISCLAIMER}

This report was prepared as an account of work sponsored by an agency of the United States Government. Neither the United States Government nor any agency Thereof, nor any of their employees, makes any warranty, express or implied, or assumes any legal liability or responsibility for the accuracy, completeness, or usefulness of any information, apparatus, product, or process disclosed, or represents that its use would not infringe privately owned rights. Reference herein to any specific commercial product, process, or service by trade name, trademark, manufacturer, or otherwise does not necessarily constitute or imply its endorsement, recommendation, or favoring by the United States Government or any agency thereof. The views and opinions of authors expressed herein do not necessarily state or reflect those of the United States Government or any agency thereof. 


\section{DISCLAIMER}

Portions of this document may be illegible in electronic image products. Images are produced from the best available original document. 


\section{DISCLAIMER}

"Ihis book was prepared as an accuunl of woik spunsuied by an agency of the United States Government. Neither the United States Government nor any agency thereof, nor any of their employees, makes any warranty, express or implied, or assumes any legal liability or responsibility for the accuracy, completeness, or usefulness of any information, apparatus, product, or process disclosed, or represents that its use would not infringe privately owned rights. Reference herein to any specific commercial product, process, or service by trade name, trademark, manufacturer, or otherwise, does not necessarily constitute or Imply its endorsement, recommendation, or favoring by the United States Government or any agency thereof. The views and opinions of authors expressed herein do not necessarily state or reflect those of the United States Government or any agency thereof."

This report has been printed directly from copy supplied by the originating organization. Although the copy supplied may not in part or whole meet the standards for acceptable reproducible copy, it has been used for reproduction to expedite distribution and availability of the information being reported.

Available from the National Technical Information Service, U. S. Department of Commerce, Springfield, Virginia 22161.

Price: Paper Copy $\$ 8.00$

Microfiche $\$ 3.50$ 
LOW COST SOLAR ARRAY PROJECT

Large Area Silicon Sheet Task

SILICON WEB PROCESS DEVELOPMENT

QUARTERLY REPORT

July 1 to September 301979

This book was pregared as an account of wark sponsored by an agency of the United States Government. Neither the Unitged States Governmeni nor any agency thereot. nor any of their employees, makes any

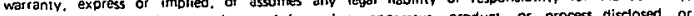

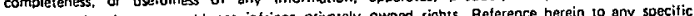

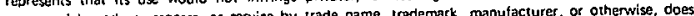
commercial praxuct, process. Or maly its endorsement, recommendation. or tavoring by the United

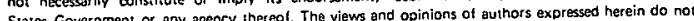
necessarily statc or reflect those of the United States Governmemt or any ogency thereot.

C. S. Duncan, R. Seidensticker, R. H. Hopkins,

J. P. McHugh, F. E. Hil1, M. E. Skutch, J. M. Driggers

Westinghouse Research \& Development Center

Pittsburgh, Pennsylvania 15235

Contract No. NAS 954654

"The JPL Low-Cost Silicon Solar Array Project is sponsored by the U. S. Department of Energy and forms part of the Solar Photovoltaic Conversion Program to initiate a major effort toward the development of low-cost solar arrays. This work was performed for the Jet Propulsion Laboratory, California Institute of Technology by agreement between NASA and DOE."

\section{Westinghouse R\&D Center 1310 Beulah Road Pittsburgh, Pennsylvania 15235}




\section{TECHNICAL CONTENT STATEMENT}

"This report was prepared as an account of work sponsored by the United States Government. Neither the United States nor the United States Department of Energy, nor any of their employes, nor any of their contractors, subcontractors, or their employees, makes any warranty, express or implied, or assumes any legal liability of responsibility for the accuracy, completeness of usefulness of any information, apparatus, product or process disclosed, or represents that its use would not infringe privately owned rights." 
TABLE OF CONTENTS

Page

1. SUMMARY. . . . . . . . . . . . . . . . . . . . . 1

2. INTRODUCTION . . . . . . . . . . . . . . . . . . . 2

3. TECHNICAL PROGREGS . . . . . . . . . . . . . . . . . 4

3.1 Background. . . . . . . . . . . . . . . . . . . 4

3.2 Output Rate Technology. . . . . . . . . . . . . . 4

3.2.1 Evaluation of Lid/Shicld Configurations to

3.2.2 Operation of WA Furnace for Growth Speed Improvements . . . . . . . . . . . . . . . . . 11

3.2.3 Growth System Characterization and Therma1 Modeling for Equipment Design. . . . . . . . . . 14

3.2.3.1 System Temperature Measurements . . . . 15

3.2.3.2 Velocity-Thickness Measurements . . . . 16

3.2.3.3 Modeling the Performance of Lid/Shield

Configurations. . . . . . . . 18

3.3 Me1t Replenishment Development. . . . . . . . . . 25

3.3.1 Silicon Feeding Technology . . . . . . . . . . . 25

3.3.2 Melt Level Sensing System. . . . . . . . . . 30

3.4 Solar Cell Evaluation . . . . . . . . . . . . . 31

4. CONCLUSIUNS. . . . . . . . . . . . . . . . . . 34

5. PLANS FOR FUTURE WORK. . . . . . . . . . . . . . . . 35

6. NEW TECHNOLOGY ................. . . . 36

7. REFFRFNCFG . . . . . . . . . . . 37

8. AC.KNOWLEDGEMENTS . . . . . . . . . . . . . . . 38

9. APPENUILES . . . . . . . . . . . . . . . . . . . . . . . 39

9.1 Growth Run Summaries. . . . . . . . . . . . . 40

9.2 Averaged Solar Cell Data for Weh Crvstals . . . . . . 54

9.3 Updated Program Plan. . . . . . . . . . . . 56

9.3.1 Milestone Chart. . . . . . . . . . . . . . . 57

9.3.2 Program Labor Summary JPL 954654, Phase III. . . 58

9.3.3 Program Cost Summary JPL 954654, Phase III . . . 59

9.4 Engineering Drawings for the Me1t Level Sensor System . 60 


\section{LIST OF ILLUSTRATIONS}

Figure

Page

1 Combined Silicon Web Polysilicon and Wafer Cost as a Function of Area Output Rate. . . . . . . . . . . . . . 5

2 The J-181 Baseline Lid and Top Shield Configuration . . . 7

3 The Thermal Environment Around a Growing Web Crysta1. Critical Regions for Stress Generation are Noted. . . . . 8

4 The J-181 Lid and a Slitted Top Shield Designed to Reduce Inductive Coupling Effects. . . . . . . . . . . . . 10

5 The WA Growth Facility, New Unit Now Being Operated Primarily to Develop Designs Favorable to Higher Web Growth Rates . . . . . . . . . . . . . . . . . . . 13

6 J-181 Thermal Model Configuration . . . . . . . . . 23

7 Components of Web Velocity-Thickness Relationship . . . . . 24

8 Schematic Illustration of Silicon Web Melt Replenishment Geometry Including Two Chambered Crucible and Feed Hole Through Which Silicon Pellets are Added to Replace the Silicon Crystallized into Web . . . . . . . . . . . 26

9 Perforated or Solid Shields were Used to Control Temperatures at the reed End of the Gusceptor During Wel Growth. . . . . 28

10 New Crucible Barrier Design (C) Used to Eliminate Melt Dewetting Observed with Hotter End Shields. Older Designs Previously used, A and B. . . . . . . . . . . . 29

11 Comparison of Cel1 Efficiency for $16 \times 40 \mathrm{~mm}$ and 10x10mm Solar Cells Made on the Same Web Crystals . . . . . . . . . 33 


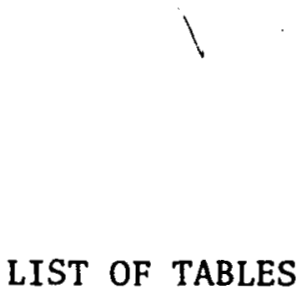

Table

Page

1 Some Recent Throughput Results . . . . . . . . . . . . . 12

2 Lid and Shield Temperatures for J-181 Configurations . . . . 17

3 Velocity-Thickness Data for J-181 Configurations . . . . . . 19

4 Coefficients from Melt Partial Velocity Calculations . . . 21

5 Cell Data for $16 \times 40 \mathrm{~mm}$ and $10 \times 10 \mathrm{~mm}$ Test Cells Made on the

Same Web Crysta1s. . . . . . . . . . . . . . . . 32 


\section{SUMMARY}

Silicon dendritic web is a ribbon form of single crystal silicon produced from the melt without die shaping, and capable of fabrication into the second quarterly report on Phase: III of a DOE/JPLsponsored effort to develop silicon web process technology for the production of low cost terrestrial solar cells and arrays.

We have recently produced the widest silicon web crystal $47 \mathrm{~mm}$, and demonstrated the highest web area output rate to date, $27 \mathrm{~cm}^{2} / \mathrm{min}$. The latter result is particularly significant. Web growth at this rate sustained by means of melt replenishment for prolonged periods produces a projected web wafer cost (including polysilicon) about equal to the JPL 1986 sheet cost objective even if $\$ 25 / \mathrm{kg}$ silicon is used for feedstock. When $\$ 10 / \mathrm{kg}$ silicon becomes available the projected web wafer cost falls significantly. below the JPL cost goal.

Melt replenishment technology development is thus a key requirement for the web process. Recently we demonstrated five hours of simultaneous web growth from a melt replenished by silicon pellets injected at a controlled rate. This is more than double the previous best result. A laser melt level sensor required to monitor melt position for closed 1oop control of the replenishment rate has been designed. The components have been procured, and the sub system is now in final assembly stages.

Direct measurements of web system temperatures coupled with determinations of web growth parameters have been used to verify the computer model developed for the web process. This tool can now be used with some confidence to guide the design of system components to improve web area output rates. We have also verified the correlation between cell performance predicted from $1 \mathrm{~cm}^{2}$ diagnostic solar cells and larger arca devices made on web. Cell efficiencies of 12 to $14 \%$ are typical even for experimental crystals produced under unoptimized growth conditions 


\section{INTRODUCTION}

Silicon dendritic web is a ribbon form of silicon which grows directly from the melt without dies and can produce solar cells with AM1 conversion efficiency over $15 \%$. The primary objective of this program is to develop the technology to produce silicon web at a cost compatible with the national goal of 50 cents per peak watt ( 70 cents per watt in 1980\$) of photovoltaic output power. This is the second quarterly report of the Phase. III effort under JPL Contract 954654, Silicon Web Process Development, and covers the period July 1, 1979 to September $30,1979$.

Readers are referred to Reference 1 for a detailed description of the major technical results underlying the development of silicon web for low cost solar cells. Briefly, we showed there that most of the technical requirements to meet the 1986 cost goals have now been demonstrated. However, to sustain the necessary area output rates, and to grow web for periods long enough to attain economic viability, the development of an operational melt replenishment system and closedloop growth system controls were identified as necessary. These two developments thus form major objectives for the Phase III effort.

Besides the development of replenishment and control techniques, the Phase III technical effort also calls for the systematic evaluation of advanced thermal trimming techniques to increase web width and speed still furthcr, for coupling of output rate and replenishment technologies, design of a semi-automated experimental web growth machine, for detailed characterization of web material produced during the experimental program, and for an update of the economic analysis to reflect new technical and cost information generated during the program. 
During the period covered by this report the dominant activities have been to improve web width and output rate and to increase the period of simultaneous growth of web crystal with melt replenishment. Significant advances have taken place in both areas, and the highlights of the work are presented in the text. We have also collected and analyzed data to characterize the performance of specific growth geometries, validate computer models of web growth and use this information as a design tool for future advances in web growth hardware. Finally, we have verified that the performance of web solar cells projected from diagnostic test cells is representative of larger area cell efficiency. 


\section{TECHNICAL PROGRESS}

\subsection{Background}

The experimental philosophy of the web development program has been to conduct parallel efforts to increase web width and growth velocity, combine these elements as advances in each technology are achieved to provide an overall improvement in area output rate. Similarly, melt replenishment technology, a requirement for sustained high output rate growth, ${ }^{1}$ is undergoing concurrent development.

During this reporting period the primary emphasis of our activities has been to increase both web output rate and the time period for simultaneous growth with replenishment. Considerable success was achieved in both areas: a new maximum output rate of $27.1 \mathrm{~cm}^{2} / \mathrm{min}$ was reached, and five hours of growth with replenishment was accomplished. The highlights of this work are presented in the following sections; detailed summaries of all experimental runs are tabulated in the Appendices.

\subsection{Output Rate Technology}

During the past quarter the $J$-furnace was dedicated largely to a study of those parameters affecting web width; the new WA furnace was applied to growth velocity experiments. The impact of top shield configuration on stress-induced deformation and general growth behavior was a major topic of the $J$-furnace experiments. In the course of the work new highs in web width, $47.1 \mathrm{~mm}$, and web output rate, $27.1 \mathrm{~cm}^{2} / \mathrm{min}$ were reached. As Figure ta cost analysis based on SAMICS - IPEG methodology 1 -emphasizes, even with $\$ 25 / \mathrm{kg}$ silicon the projected silicon web wafer cost (including polysilicon) falls below the JPL 1986 goal when the demonstrated $27.1 \mathrm{~cm}^{2} / \mathrm{min}$ output rate can be sustained by me1t replenishment to provide continuous automated growth. 
Curve $713010-A$

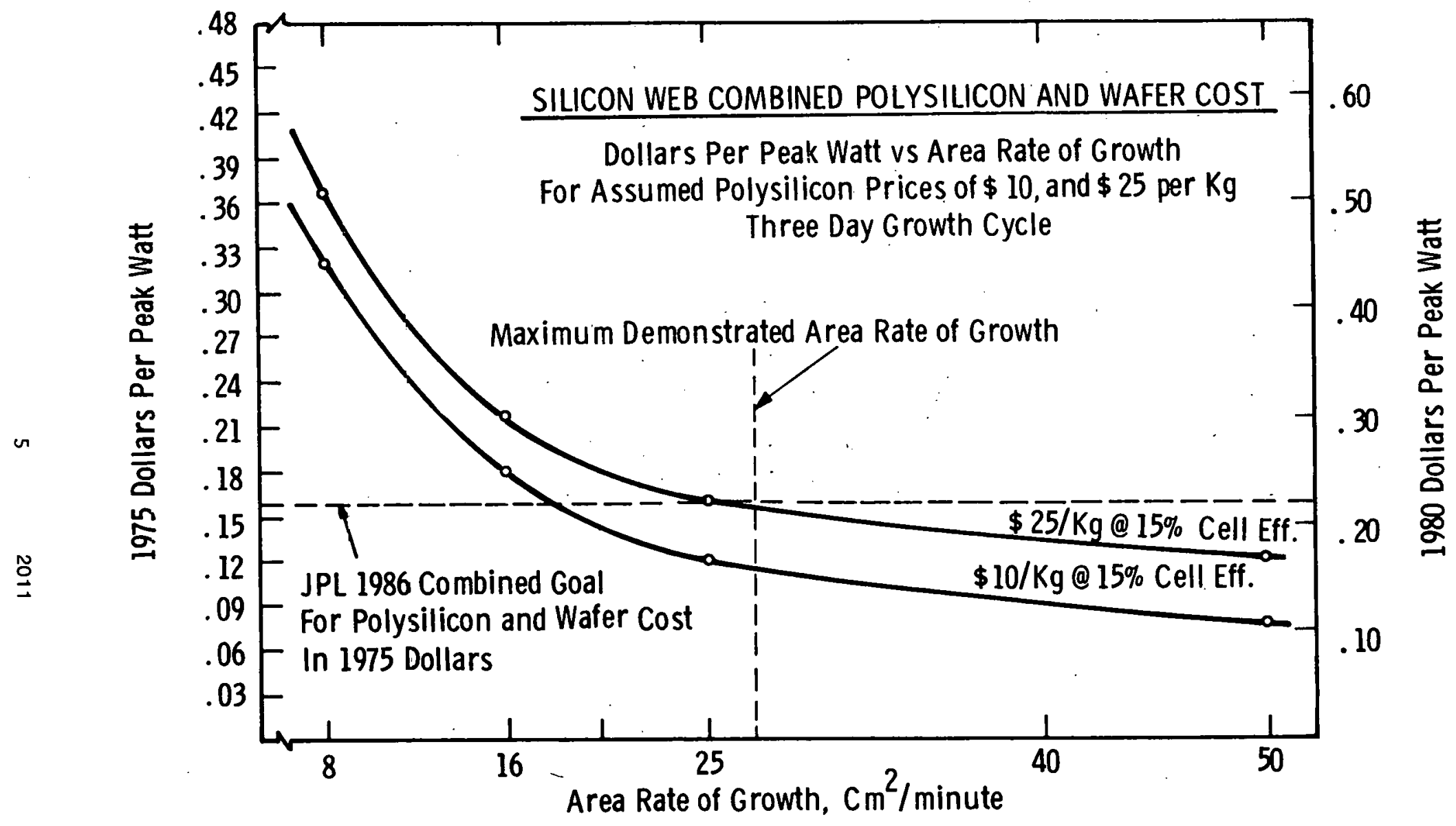

Figure 1 Combined silicon web polysilicon and wafer cost as a function of area output rate. 
Beside the output rate studies themselves, effort was made to measure accurately the lid and shield temperatures corresponding to actual growth conditions-important input data to our computer simulations of web growth. Thickness-velocity data, key tools for characterizing the effectiveness of specific growth geometries, were also determined.

\subsubsection{Evaluation of Lid/Shield Configurations to Increase Web Width}

Our previous experimental results led to the development of the J-181 lid/shield configuration, Figure 2, a geometry which yielded wide crystals and produced relatively slable growth conditions. As part of a series of experiments to characterize this configuration we recent1y produced the widest web crystal so far grown, $47.1 \mathrm{~mm}$. Because of the excellent results obtained this configuration became a baseline for modifications designed to further raise web output rate. These modifications included variations in the number of top shields, shield spacing and shield temperature. These changes serve to adjust the vertical temperature distribution that the web "sees" and thus tho tomperature profile in the web itself. In this way, the thermally generated elastic stress in the web can be reduced, deformation eliminated and web width increased. 1

The rationale for the approach is suggested schematically in Figure 3 which depicts the thermal environment surrounding a growing web crystal. As the figure illustrates, a critical region is that. one to two centimeters above the crystal-1iquid interface where manipulation of the thermal profile affects the generation of elastic stress. Previous thr.rmnl modeling of weh growth ${ }^{l}$ indicated that reduction in the temperature of the outermost thermal shield reduces stress and thus should improve web width. Growth speed should also be raised: (This result was borne out initially in developing the J-181 configuration ${ }^{1}$ ). 


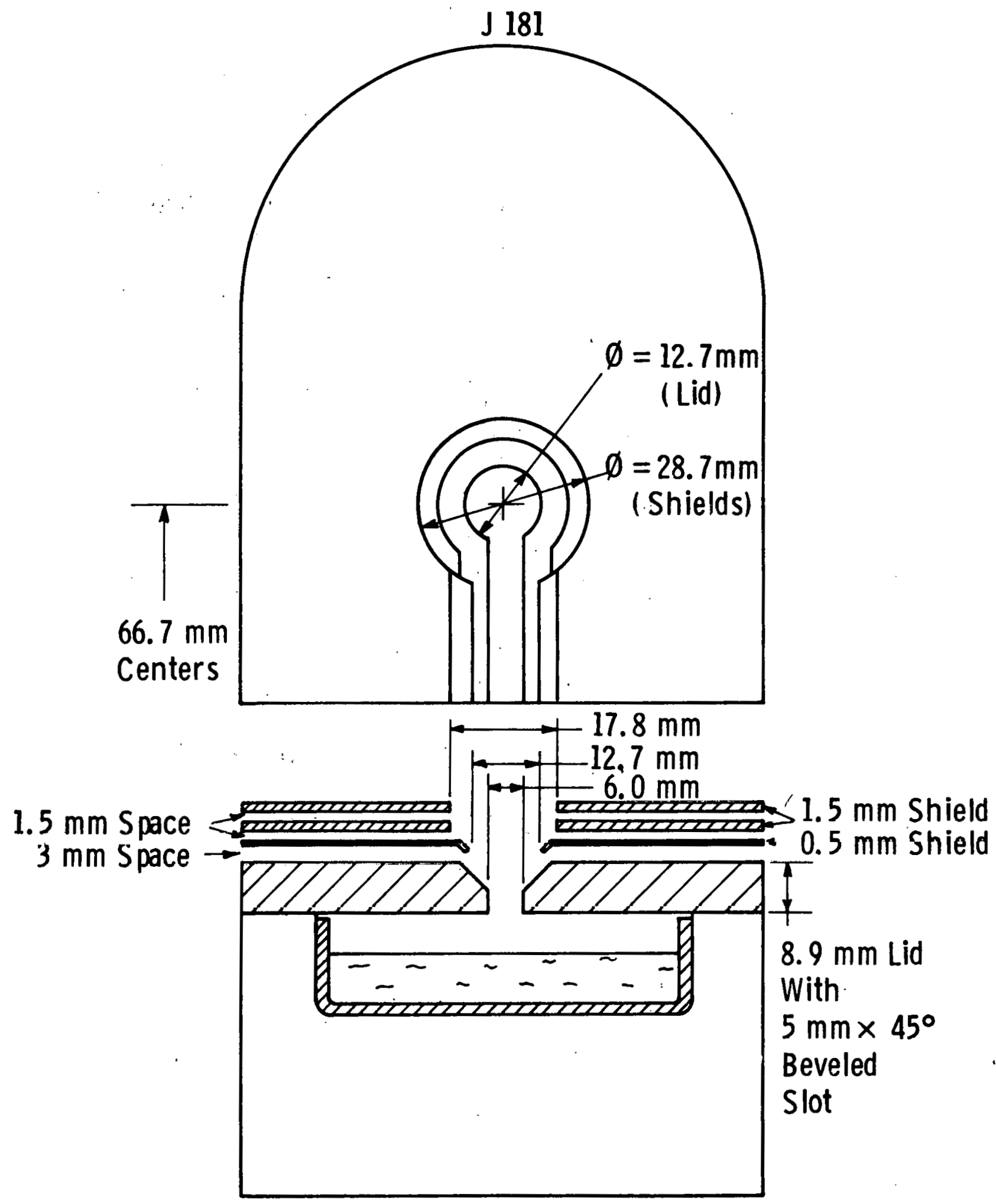

Figure 2 The J-18I Baseline Lid and Top Shield Configuration 
Dwg. $7701 \mathrm{A17}$

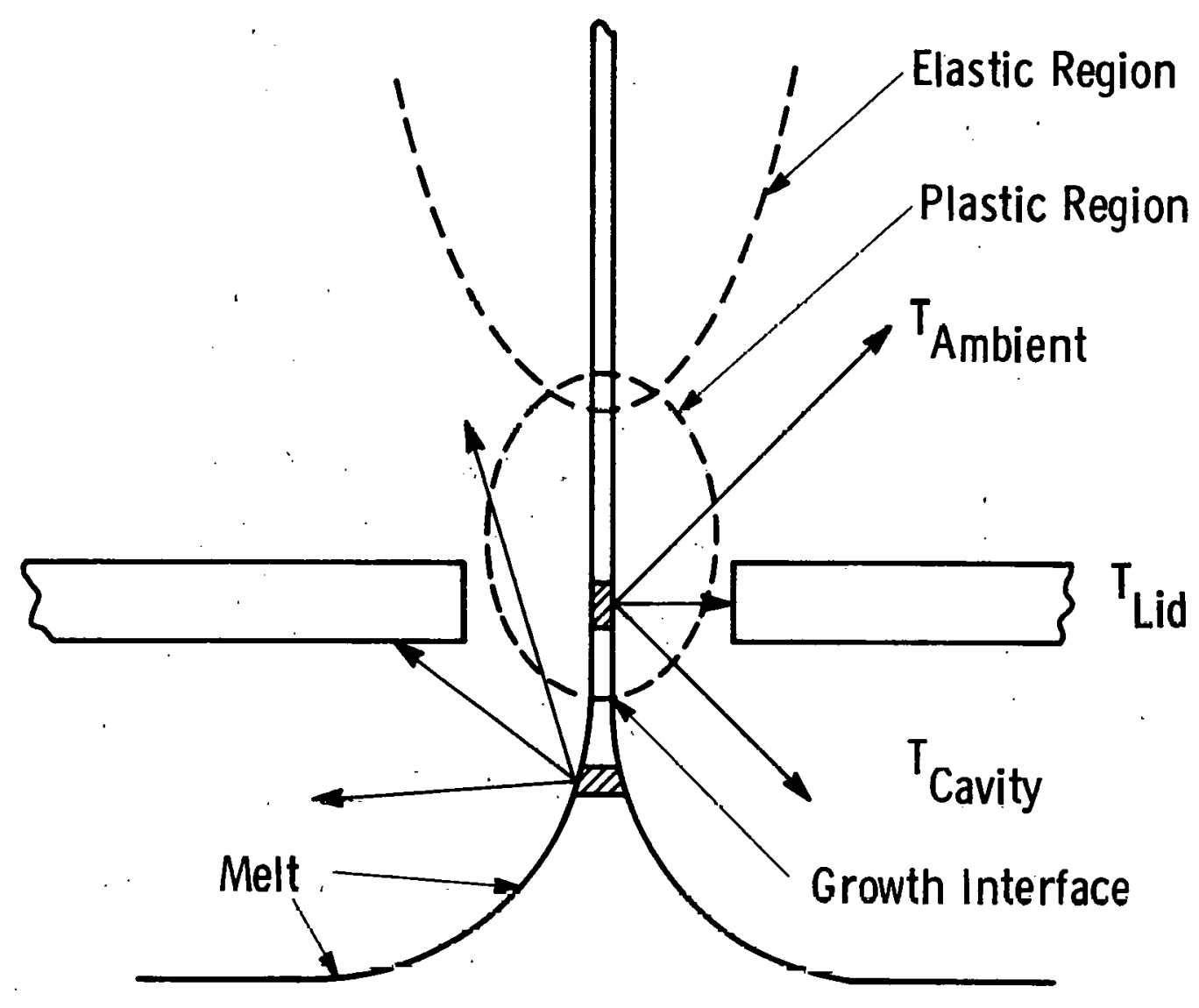

Figure 3 The thermal environment around a growing web crystal. Critical regions for stress generation are noted. 
Thus the next step was to add an additional, or fourth, thick ( $1.5 \mathrm{~mm}$ ) shield to the J181 stack to further reduce top shield temperature. The result was negative; for this configuration seeding and button initiation were difficult, and polycrystalline starts occurred frequently. However, when a thin $(0.5 \mathrm{~mm})$ shield was placed directly on top of the third shield of the J181 stack (Figure 2), excellent results were achieved. The highest output rate attained to date, $27.1 \mathrm{~cm}^{2} / \mathrm{min}$ was achieved with this configuration.

A drawback to the thin shield approach is that the shield can become warped with repeated usage. This diminishes the day to day reproducibility for the configuration and its utility in an engineering sense. Other related configurations, e.g. $\mathrm{H} 187$ (see Appendix) exhibited some of the same difficulties, nevertheless the principle of operation for high output rate was demonstrated.

Simply stacking extra shields to reduce top shield temperature is not a completely efficient approach because the shields themselves can couple inductively and thus be heated in the same way that the lid and susceptor heat. This reduces their shielding effectiveness. For this reason modifications were made to the shields themselves to reduce the coupling effect. This was accomplished by slitting the periphery of the shield, see Figure 4. The reduction in coupling to the shields is quite evident visually-they glow much less on heating than comparable unslitted shields-and also from actual measurements of shield temperatures (see section 3.2 .3 ).

Utilizing this concept we have begun a series of experiments in which the position and spacing of the slotted shields are varied systematically with the J181 lid as a basis. So far a major attribute of these "cold" shields is that they provide extremely stable growth conditions. Initiation of growth is easy, and once started, the web crystals propagate with only occasional operator surveillance and parameter adjustment. The next series of experiments will involve reducing the height of the shield stack which model calculations and initial experience suggest should be beneficial for controlling elastic stress and further raising web width. 


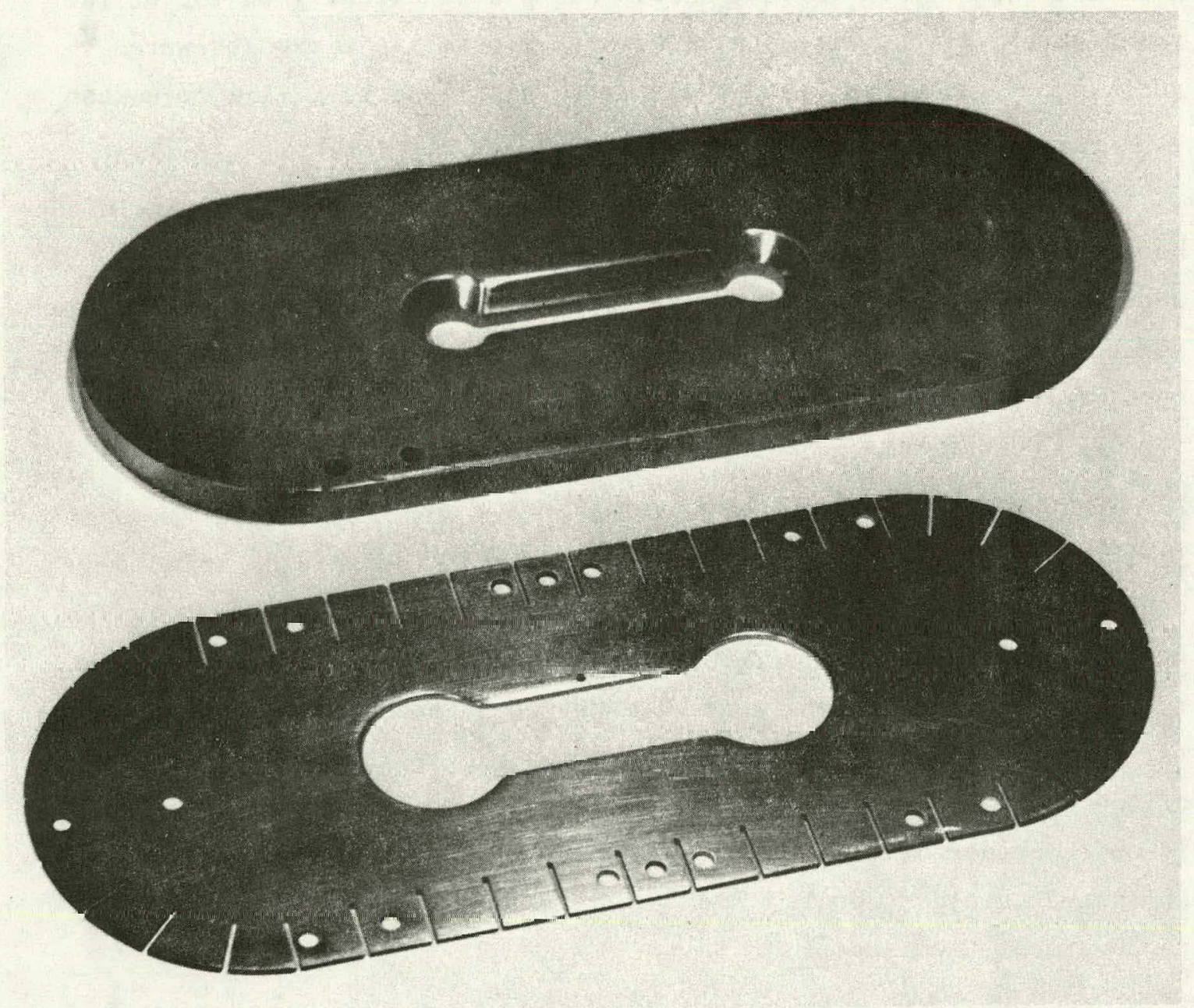

Figure 4 The J-181 lid and a slitted top shield designed to reduce inductive coupling effects. 
In summary, the arrangement and type of top shield provides a sensitive method to shape the temperature distribution in the web which affects web width, speed and output rate. Reducing the upper shield temperature has been very beneficial, as some of the recent J-furnace data compiled in Table 1 suggest. An added impact, improvement of growth stability can also be achieved this way. Beyond this, the trend of the results are in qualitative agreement with predictions from our thermal model of web growth. ${ }^{1}$ Thus, as more quantitative results are obtained from the modeling (see section 3.2.3) to guide the design of $1 \mathrm{id} / \mathrm{shield}$ configurations we anticipate still further improvements in output rate.

\subsubsection{Operation of WA Furnace for Growth Speed Improvements}

During this quarter a new web furnace designated WA was made operational. The new furnace, pictured in Figure 5, has capabilities similar to the $J$ and RE furnaces but is somewhat simplified in design compared to those units ${ }^{2}$. Twenty runs have been completed to date with this equipment (see Appendix for details). The primary objectives of this initial work have been to assure that all furnace systems operated satisfactorily and then to begin studies designed to increase web growth velocity.

In the first series of runs the furnace was checked for leaks, and to assure that the argon gas system and temperature controls functioned properly. A calibration of pull speed and temperature adjustments was also made. Following the initial shakedown activities several runs were made with two standard growth configurations, RE-1 and J-181 for purposes of comparing growth behavior in the WA furnace with that in the $\mathrm{J}$ and $\mathrm{RE}$ furnaces. The first runs of this kind were hindered by the accumulation of oxide near the edges of the growth slot and on some portions of the shields. This problem (which also developed during early runs on the other equipment) was eliminated by improving preparation of the shield cleaning coupled with minor modifications in the me1t down procedure and in the way the heat shields were positioned for growth. A succession of oxide free runs followed in which no aspirators or other gas flow management schemes were required to maintain system cleanliness. 
TABLE 1 SOME RECENT THRUPUT RESULTS

\begin{tabular}{lccc} 
Run No. & $\begin{array}{c}\text { Throughput } \\
\mathrm{cm}^{2} / \mathrm{min}\end{array}$ & $\begin{array}{c}\text { Width } \\
\mathrm{mm}\end{array}$ & $\begin{array}{c}\text { Growth Velocity } \\
\mathrm{cm} / \mathrm{min} .\end{array}$ \\
\cline { 1 - 2 } $\mathrm{J}-189$ & 16.6 & 36.0 & 4.5 \\
$\mathrm{~J}-192$ & 18.7 & 36.0 & 5.2 \\
$\mathrm{~J}-195$ & 21.5 & 35.8 & 6.0 \\
$\mathrm{~J}-196$ & 27.1 & 35.7 & 7.6 \\
$\mathrm{~J}-200$ & 15.8 & 47.2 & 3.3 \\
$\mathrm{~J}-212$ & 16.5 & 32.9 & 5.0 \\
$\mathrm{~J}-213$ & 16.6 & 32.0 & 5.2
\end{tabular}




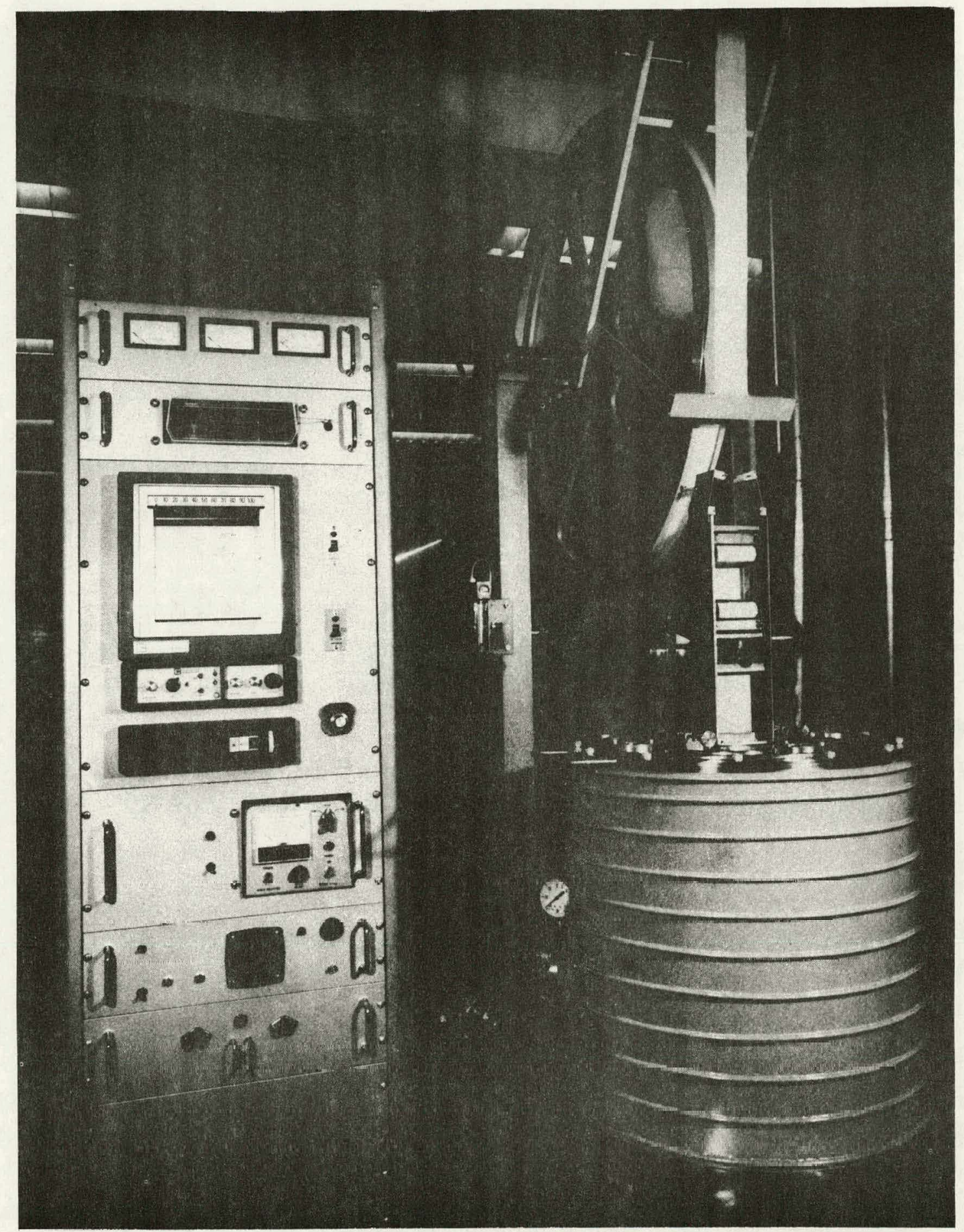

Figure 5 The WA growth facility, new unit now being operated primarily to develop designs favorable to higher web growth rates. 
Experiments to test methods for increasing web growth velocity were initiated at this point. Improvements in growth velocity hinge on increasing the transport of the latent heat of fusion out of the growing crysta1. ${ }^{1}$ As Figure 3 suggests one of the most effective ways to do this is to raise the amount of radiative heat loss from the web. This can be accomplished by reducing the bevel angle on the growth lid so that the radiative view factor is made correspondingly greater. Shields folded over the hot bevel section can also be used to reduce radiative transport to the web. In the first experiments the standard $45^{\circ}$ bevel was replaced by a $30^{\circ}$ bevel on the growth lid. The modified lid design resulted in about a twenty per cent increase in growth velocity compared to the standard $45^{\circ}$ bevel used with the same top shields. Future experiments will test the use of top shields spaced more closely together and folded over the bevel to improve speed.

\subsubsection{Growth System Characterization and Thermal Modeling for Equipment Design}

An important adjunct to the web growth studies themselves is development of a data base characterizing specific system configurations and analysis techniques to provide design guidance for future improvements. Thus we recently have been evaluating and improving the correlation between observed web growth behavior and the mathematical models which describe the growth process. As noted earlier, qualitative agreement between the computer simulation ${ }^{1}$ and measurement has been good but quantitative agreement is hindered because some parameters, such as lid and shield temperatures, used in the model are known only approximately. The purpose of the work described below is to give better insight into the relationship between the imposed growth conditions and the way web actually grows and to identify directions for improved system design.

The first step toward developing system designs with enhanced output rates is to evaluate just how well the model used for design guidance actually describes the performance of a specific growth geometry. To accomplish this actual temperatures at critical regions 
had to be measured, and a suitable growth parameter to compare with the model had to be identified.

The most important system parameters seem to be the temperature at the slot in the susceptor lid and the concomitant temperature of the top susceptor shield. The choice of growth parameter is less direct. The most appropriate data would be the temprature distribution along a growing web. However,the task of measuring this profile with the necessary accuracy in both temperature and position is formidable. A relatively simple measurement, that of the ribbon thickness as a function of velocity, provides a great deal of information, especially the initial slope of the temperature distribution. The following subsections describe these measurements as well as the validation of the thermal model.

\subsubsection{System Temperature Measurements.}

To provide data for the thermal modeling and lid design effort, thermocouple measurements were made of the lid and the top shield temperatures of a J181 configuration (see Figure 2) with the melt at the "hold temperature". Small holes were drilled in the lid and shield near one side of the mid position of the slot, such that the thermocouple beads were centered in the thickness dimensions. The lid. temperature was measured with a Type B (Pt-30\%Rh/Pt-6\%Rh) couple with the bead inserted deeply into the material; the long "immersion depth" created by running the leads between the lid and the first top shield would minimize temperature measurement errors. The top shield temperature was measured by a Type $K$ (Chromel-Alume1) couple and in this case, the bead was, secured in the hole with an alumina slurry cement to assure thermal contact. The thermocouple outputs were fed into a data logger and monitored until a steady state thermal situation was reached.

Two modifications of the J181 configuration were analyzed. In the first configuration (baseline) the $1.5 \mathrm{~mm}$ thick top shields were solid and thus coupled to some extent with the induction field. In the second modification, the periphory of thc top shields was interrupted with slits $12 \mathrm{~mm}$ deep about $1 \mathrm{~mm}$ wide and spaced every $12 \mathrm{~mm}$ as in Figure 4. 
The intent of this modification was to reduce the inductive coupling to the shields, and this was successful as can be seen from the data, Table 2. The data also show that the lid temperature is relatively insensitive to coil height, while the top shield temperature is more strongly affected. When these data were compared with the temperatures previously used in the thermal modeling, it was found that the measured lid temperature was about $50^{\circ} \mathrm{K}$ colder than originally assumed, ${ }^{1}$ but that the shield temperatures were from $50^{\circ} \mathrm{K}$ to $150^{\circ} \mathrm{K}$ hotter than had been assumed on the basis of a radiation equilibrium between the lid and shields. Even in the case where the shields were slit, it appears that the top shield is somewhat hotter than anticipated. This may be due in part to conductive transport of heat through the gas and in part to some residual heating by the induction field. In any case, apparently reliable data is now available for use in future thermal modeling.

\subsubsection{Velocity-Thickness Measurements}

The relation between the thickness of a web crystal and its growth velocity is dependent on the rate at which the latent heat of fusion can be removed from the growth front. As such, both the heat loss to the supercooled liquid and the heat loss through the web itself make a contribution so that the interpretation of measure velocitythickness $(v-t)$ relation is not compltely unambiguous. As will be discussed later, however, the contribution from the supercooled melt can be ascertained with reasonable exactness, so that the web contribution can be extracted from the combined data.

Generation of the experimentalv-t data is straightforward; once growth is started, the pull speed on the crystal is varied incrementally to provide segments of different thicknesses. Ihe only major caution is to allow 10 to $15 \mathrm{~cm}$ of growth at each speed in order to reach steady state. If the twin planes do not grow out of the ribbon as it thins, then the speed can be set at normal rate and growth continued. There is, in fact, some suggestion that thinning the crystal may improve its quality by eliminating dislocations. 
TABLE 2 LID AND SHIELD TEMPERATURES FOR J181 CONFIGURATIONS

\begin{tabular}{|c|c|c|c|}
\hline Coil Position & Shield Type & Lid Temp.,${ }^{\circ} \mathrm{C}$ & Top Shield Temp., ${ }^{\circ} \mathrm{C}$ \\
\hline $100.0 \mathrm{~mm}$ & Solid & 1354.7 & 963.1 \\
\hline 102.7 & $"$ & 1351.3 & 941.7 \\
\hline 105.0 & . & 1344.6 & 927.4 \\
\hline 101.0 & Slitted & (open T.C.) & 878.6 \\
\hline
\end{tabular}

Note that in the coil position column, higher numbers mean a lower coil position relative to the susceptor. 
The most convenient means of presenting velocity-thickness data is to tabulate the coefficients $a$ and $b$ in the equation

$$
v=a+\frac{b}{t}
$$

where $t$ is the ribbon thickness. This empirical equation not only proves to be an excellent fit to the experimental data but also, as will be seen, is a very good representation of the modeling results. Some representative data on crystals grown from the .LI81 type lid configurations are given in Table 3 . Several minor modifications of the configuration are included and it is evident that there is very reasonable reproducibility between crystals grown from the same configuration and even among the different modifications. Rather than include the correlation coefficient for the data, the root-mean-square deviation for the velocity, $S$, is given in the table. In most cases $S$ is about 0.01 to $0.05 \mathrm{~cm} / \mathrm{min}$ which is of the order of accuracy in determining the pull speed setting, i.e about 1 division on the control dial.

One particular data set is worth notice. Crystals $\mathcal{H}_{211-1}$ and J211-5 were the first and last crystals grown in furnace run T-211. Between the growth of the two crystals, about $45 \mathrm{gm}$ of material had been drawn from the melt causing the melt level to fall about $2 \mathrm{~mm}$. This change in melt height is apparently reflected in the " $b$ " coefficient of Eq.1.

\subsubsection{Modeling the Performance of Lid/Shield Contigurations}

The approach we adopted for the modeling effort was to establish a baseline calculation for the J181 growth configuration using the measured lid and shield temperatures. The results of the calculations were then compared with experimental data to evaluate the overall validity of the model. As mentioned in the foregoing section, the simplest data which can be used for this comparison is the relationship between the web thickness and the growth velocity. In order to match the empirical data, two models must be evaluated: first, a calculation of the heat loss to the meniscus and supercooled melt, and second, a calculation 
TABLE 3 VELOCITY-THICKNESS DATA FOR J181 CONFIGURATIONS

$\begin{array}{lllcccc}\text { Crystal } & \begin{array}{c}\text { Configuration } \\ \text { (See Notes) }\end{array} & \begin{array}{c}\Delta \mathrm{T} \\ { }^{\circ} \mathrm{C}\end{array} & \begin{array}{c}\mathrm{a} \\ \mathrm{cm} / \mathrm{min}\end{array} & \begin{array}{c}\mathrm{b} \\ \mu \mathrm{m}-\mathrm{cm} / \mathrm{min}\end{array} & \begin{array}{c}\mathrm{S} \\ \mathrm{cm} / \mathrm{min}\end{array} & \text { REMARKS } \\ \mathrm{J} 197-1 & \text { Std. } & 4.3 & 1.33 & 167 & .019 & \text { Ful1 (185 gm) crucible } \\ \mathrm{J} 198-2 & \mathrm{M} 1 & 3.4 & 1.17 & 146 & .028 & 8 \text { gm removed by growth } \\ \mathrm{J} 199-1 & \mathrm{M} 1 & 5.0 & 1.17 & 154 & .029 & 5 \text { gm removed } \\ \mathrm{J} 211-1 & \mathrm{M} 2 & 3.6 & 1.17 & .150 & .006 & \text { Fu11 (185. gm) crucib1e } \\ \mathrm{J} 211-5 & \mathrm{M} 2 & 3.7 & 1.22 & 107 & .02 & 45 \text { gm removed by growth }\end{array}$

Notes: The lid configuration are as follows

Std. - Identical to Figure 2.

M1 - Added thin shield placed directly on top of J181 (std) top shield

M2 - Added heavy shield; top two shields slitted to reduce coupling. 
of the heat dissipated from the crystal itself. For all intents, these calculations are independent and the results can be conveniently expressed as partial velocities, $v_{\text {melt }}$ and $v_{\text {web }}$, with $v_{\text {total }}=v_{m}+v_{w}$.

\section{Meniscus Heat Loss}

The thermal model of the heat loss to the meniscus follows the same approach as the model for the heat loss from the web as described in appendix 6.5 of the 1978 annual report of this project. 3 For this calculation, the most critical geometrical and thermal parameters are the temperature of the susceptor 1id near the growth slot, the effective thickness of the lid itself, the width of the slot, the position of the interface below the lid, and of course the melt undercooling.

Although the geometry of the J181 configuration is well defined, a. range of parameters were modeled to evaluate the sensitivity of the melt partial velocity, $v_{m}$, to changes in the lid configuration. Although the results must be nonlinear over an extended range of ribbon thickness, the calculations proved to be a very good fit to an equation analogous to equation 1 , namely

$$
v_{m}=a_{m}+\frac{b_{m}}{t}
$$

where the subscript, $m$, implies the coefficients apply to the melt heat transfer.

The results of the current modeling, Table 4, are given in terms of the coefficients $a_{m}$ and $b_{m}$ in Eq. 2 . The most striking feature of these numbers is that they are relatively independent of the lid geometry and are mainly dependent on the melt undercooling. Furthermore, comparison with some earlier data showed that the coefficients were nearly the same even though the geometrical factors were different. Thus, an almost "universal" set of parameters $a_{m}$ and $b_{m}$ can be used to represent the partial velocity due to the melt for both modeling purposes and for analysis of experimental data. 
TABLE 4

COEFFICIENTS FROM MELT PARTIAL VELOCITY CALCULATIONS

\begin{tabular}{lccccc}
$\begin{array}{l}\Delta \mathrm{T} \\
{ }^{\circ} \mathrm{C}\end{array}$ & $\begin{array}{c}\mathrm{LIN} \\
\mathrm{mm}\end{array}$ & $\begin{array}{c}\text { LID } \\
\mathrm{mm}\end{array}$ & $\begin{array}{c}\text { SLOT } \\
\mathrm{mm}\end{array}$ & $\underline{\frac{a_{\mathrm{m}}}{\mathrm{cm} / \mathrm{min}}}$ & $\begin{array}{c}\mathrm{b}_{\mathrm{m}} \\
\underline{\mu m-\mathrm{cm} / \mathrm{min}}\end{array}$ \\
\hline 4 & 1 & 6 & 6 & .32 & 75 \\
4 & 1 & 10 & 6 & .31 & 72 \\
4 & 2 & 6 & 6 & .31 & 74 \\
4 & 2 & 10 & 6 & .30 & 71 \\
2 & 2 & 10 & 6 & .19 & 41 \\
6 & 2 & 10 & 6 & .41 & 99
\end{tabular}

$$
\begin{aligned}
& \Delta T=\text { melt undercooling } \\
& \text { LIN }=\text { interface distance below lid } \\
& \text { LID }=\text { effective lid thickness } \\
& \text { SLOT }=\text { slot width } \\
& a_{m}, b_{m}=\text { cocfficients in } v_{m}=a_{m}+b_{m} / t
\end{aligned}
$$




\section{Web Heat Loss}

The temperature distribution and concomitant heat fluxes were calculated for the J181 $\mathrm{lid}$ and shield configuration using the experimental lid and shield temperatures in the model. The basic features of the model are shown in Figure 6 in which the actual J181 configuration is compared with the model parameters. Temperature/heat flux data was calculated for three web thicknesses, 100, 150 and $250 \mu \mathrm{m}$ in order to derive a velocity-thickness curve. The three temperature curves were very nearly the same except for a few millimeters near the interface. Again it was found that for the range of crystal thicknesses involved the data could be represented well by an equation of the torm

$$
v_{w}=a_{w}, \frac{b_{w}}{t} .
$$

where the subscript $w$ implies the coefficients are for the web. A fit to the data with $a_{w}=0.88$ and $b_{w}=64$ exhibited an rms deviation from linearity of $0.014 \mathrm{~cm} / \mathrm{min}$.

\section{Combined Results}

Since the form of the velocity-thickness is the same for both the melt and the web partial velocities, the like coefficients can be summed to give the total velocity as illustrated in Figure 7 . The result can be expressed explicitly as

$$
v_{t}=\left(a_{m}+a_{w}\right)+\frac{\left(b_{m}+b_{w}\right)}{t} .
$$

For the present modeling results, this gives

$$
v_{t}=1.19+\frac{137}{t} \text {. }
$$

where $t$ is in $\mu \mathrm{m}$ and $v$ is in $\mathrm{cm} / \mathrm{min}$. 
Dwg.7709A12

\begin{tabular}{|c|c|c|c|c|c|c|}
\hline TC & TS & TBEVEL & TAS & TLID & ZD & $\mathrm{ZH}$ \\
\hline 1623 & 1460 & .6 & 1213 & 1.0 & 1.35 & 1.85 \\
\hline & & & & & & \\
\hline & & & & & & \\
\hline & & & & & & \\
\hline & & & & & & \\
\hline & & & & & & \\
\hline
\end{tabular}

Dimensions in $\mathrm{CM}$

- Temp. in ${ }^{\circ} \mathrm{K}$

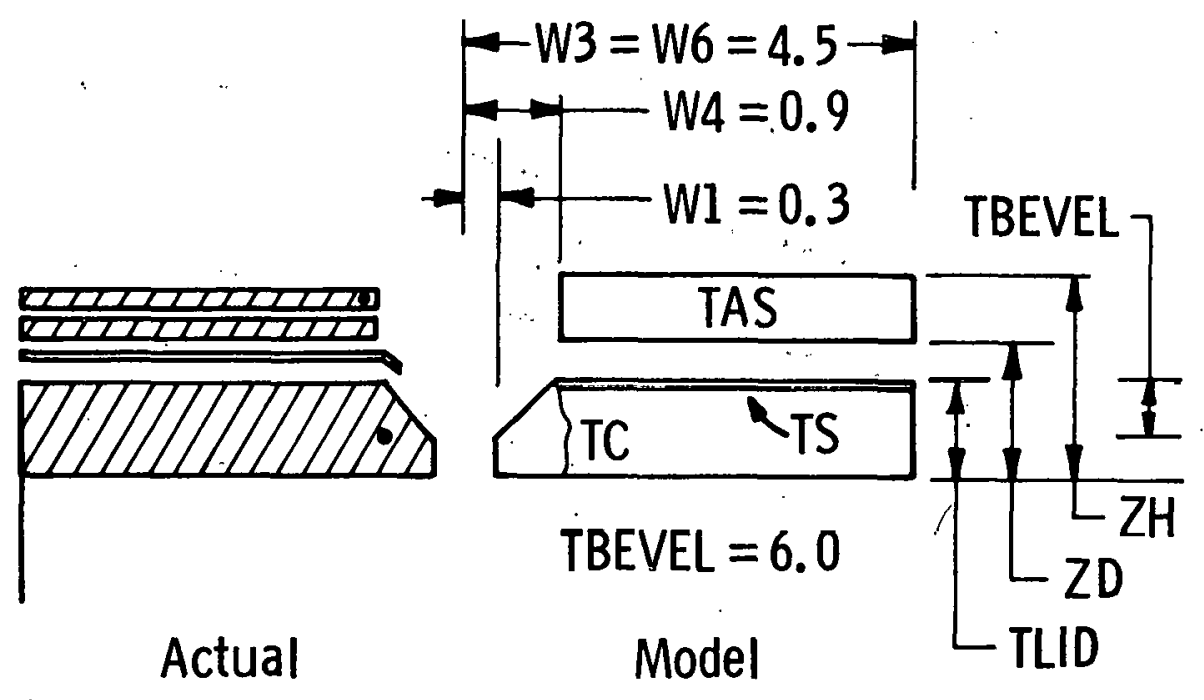

- Thermocouple Location

Figure 6 J181 Thermal Model Configuration 


$$
v_{\text {total }}=v_{\text {melt }}+v_{\text {web }}
$$$$
v_{i}=a_{i}+\frac{b_{i}}{t} \quad i=\text { total, melt or web }
$$

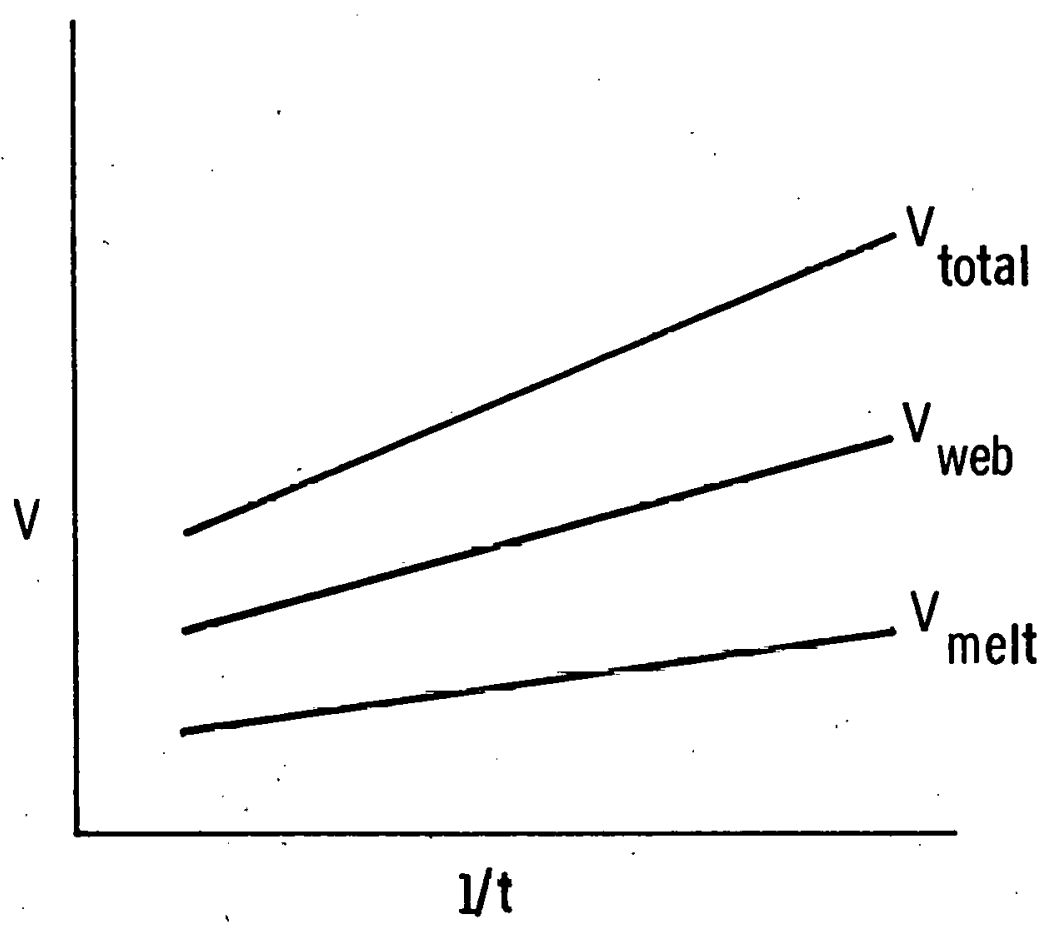

Figure 7 Components of web velocity-thickness relationship 
The model results should be compared with the experimental results given in Table 3 . Omitting the data for J211-5, which represents a melt lowered by several millimeters from the other cases, the average coefficients are $a_{\text {expt }}=1.21 \pm .08$ and $b_{\text {expt }}=154 \pm 9$. These numbers can be compared with the model results of $a_{t}=1.19$ and $b_{t}=139$. The agreement is quite good, especially considering the fact that the experimental data represents a (smal1) range of melt heights and supercoolings. The present model is apparently a good tool for predicting the velocity-thickness characteristics of new lid designs and will be applied in the near future to guide the development of designs for improved output rate performance.

\subsection{Melt Replenishment Developement}

\subsubsection{Silicon Feeding Technology}

As described previous $1 y^{1,2}$ we have shown that melt replenishment is required to sustain high output rate web growth for prolonged periods, and that a feasible method to do this is to feed silicon pellets at a programmed rate as the web is grown. The experimental configuration is depicted in Figure 8 . The thrust of the current development effort is to extend the period of growth with replenishment to practical operating periods. Two types of studies have been carried out during the past quarter (1) replenishment with restricted growth slots to control web width and (2) replenishment with wide growth slots like the J181 configuration. Key results of the activity are given here; the details of all runs (conducted in the RE furnace) appear in the Appendix.

The initial runs this quarter were to investigate methods to control web width while feeding. The purpose was to provide an extended growth period by controlling web width below the $47 \mathrm{~mm}$ size at which stress-induced bending is observed (see section 3.2). Adjustable shields (molybdenum pieces) were placed over the ends to the growth slot to manipulate the melt temperature profile and thus control web width. We observed a decrease in widening rate by this approach and in fact were able to control web width within about $2 \mathrm{~mm}$ for 1 engths up 
Dwg. 7699A80

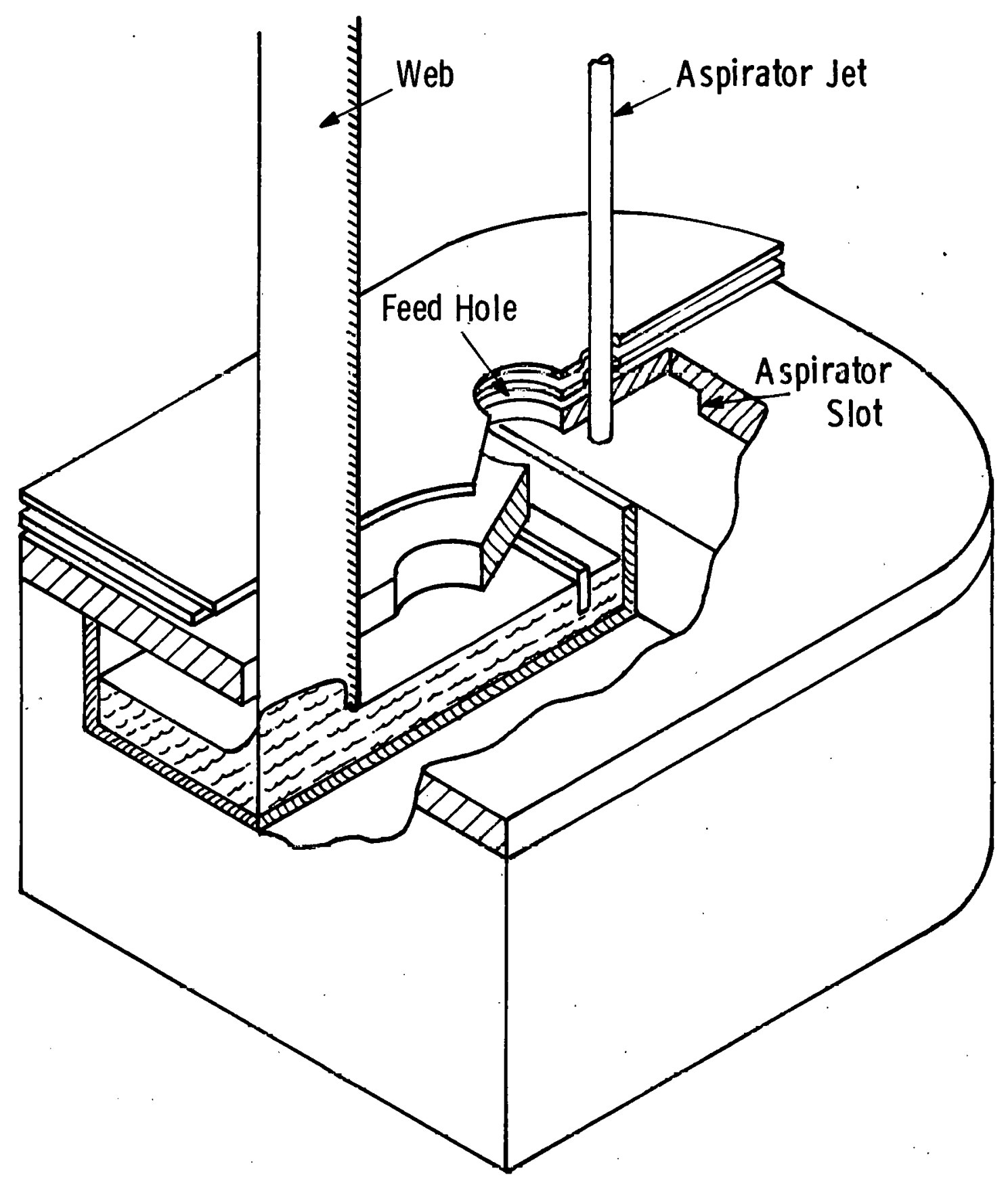

Figure 8 Schematic illustration of silicon web melt replenishment geometry including two-chambered crucible and feed hole through which silicon pellets are added to replace the silicon crystallized into web. (The argon jet helps eliminate oxide collection near feed hole and growth slot 2). 
to about a meter. It was difficult to grow for more extended periods due to the accumulation of silicon oxide on the moveable molybdenum shields. Although the principle appears to work, alternative engineering approaches will have to be taken to implement the idea.

The next series of runs employed a J181 lid configuration. Variations in the type and amount of thermal shielding placed on the feed end of the susceptor, Figure 9 , were made to evaluate their effect on the rate of pellet melting during replenishment. Two types of end shields, perforated and solid, were tested. The fraction of the shield perforated was used to control the radiative heat loss from the susceptor end and thus adjust the heat balance.

The perforated shields never performed satisfactorily; silicon tended to freeze in the feed and growth chambers when pellets were fed into the liquid. Adjustments to the aspirator argon flow rate and to the work coil position failed to eliminate the problem. We concluded that solid shields would be required to keep the feed chamber sufficiently hot to melt the pellets at an acceptable rate.

Following some modifications to the crucible barrier arrangement, a replenishment run utilizing the solid end shield produced the longest sustained period of web growth with replenishment to date, five hours. During this time pellets were fed at about half the rate required for full output rate replenishment. Three web crystals were grown, the longest for about two and a half hours. There were no feed-related problems throughout the course of the run.

Raising the replenishment/growth period beyond five hours has been hampered by two difficulties. First, melt dewetting like that previously described $^{1,2}$ occurred during several subsequent runs. This. behavior, apparently related to the hotter end temperature, has been eliminated by implementation of a new barrier design, $C$ in Figure 10 . The new design has operated successfully in the several runs since the inception of its use. 


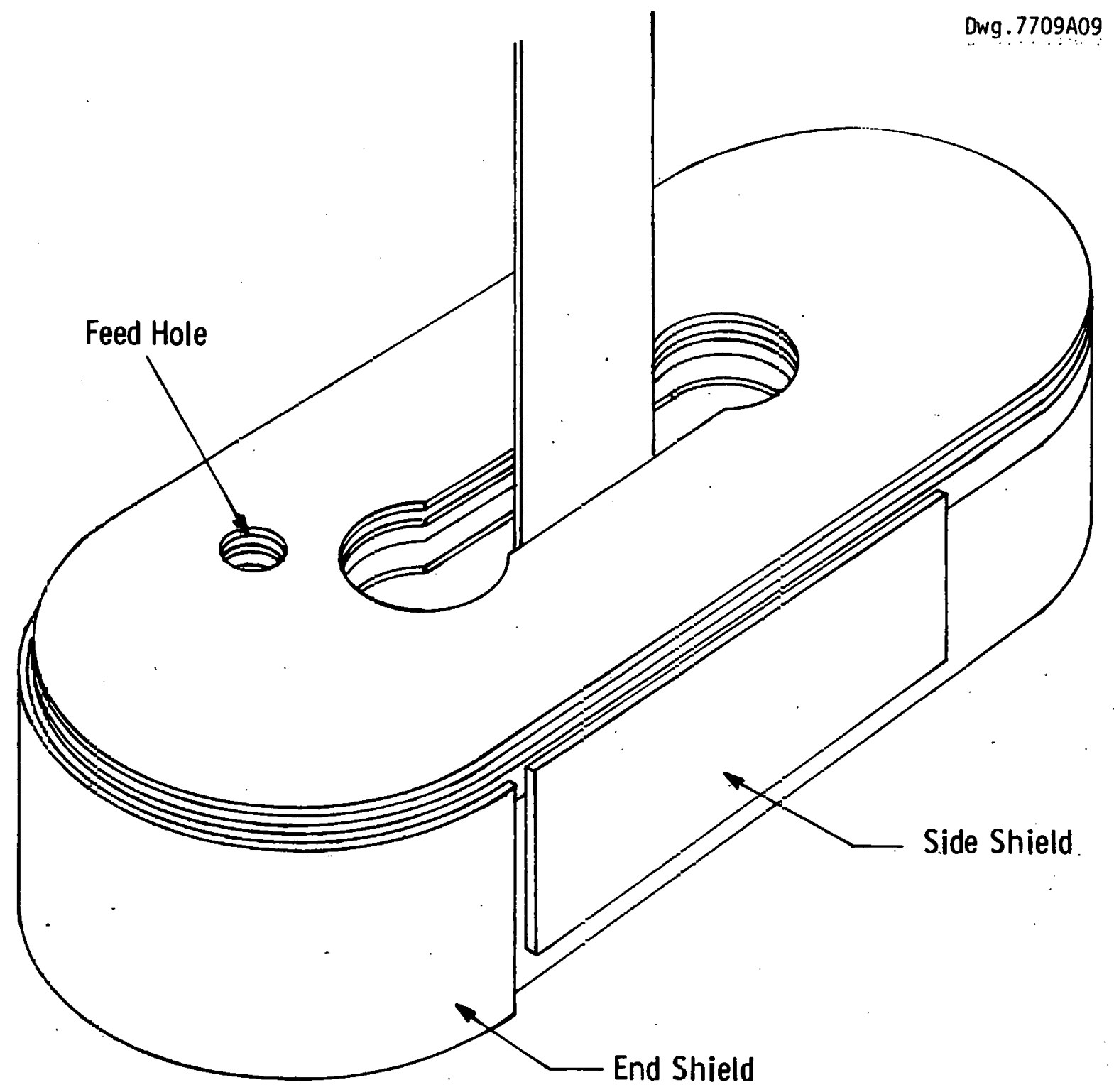

Figure 9 Perforated or solid shields were used to control temperatures at the feed erd of the susceptor during web growth. 
Dwg. 7709A08

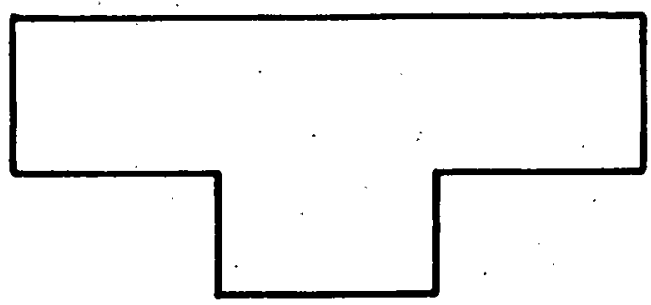

(A)

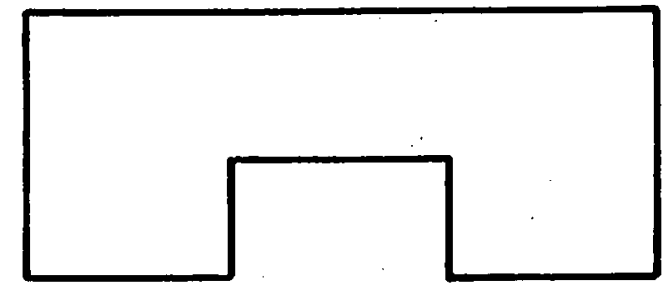

(B)

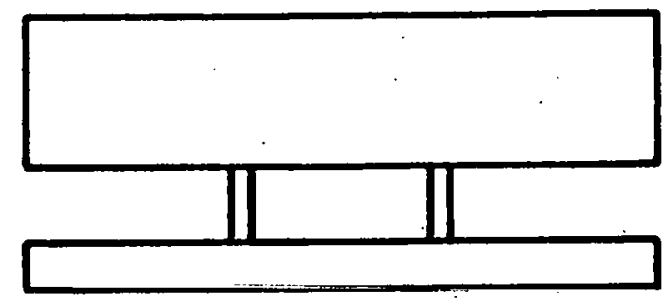

(C)

Figure 10 New crucible barrier design (C) used to eliminate melt dewetting observed with hotter end shields. older designs previously used, A and B. 
A second difficulty has been the recurrent formation of floating silicon particles, or "ice", in the growth chamber when pellets were fed into the replenishment chamber. Some of this has been traced to the spalling of oxide collected on the bottom of the growth lid. On other occasions the cause seems again to be carryover of particles from the replenishment chamber. The observations are complicated by the occurance of ice recently even when no feeding was attempted, suggesting leaks in the RE furnace or the feed system itself. To prcvent potcntial oxide carryover from the replenishment chamber, a higher crucible barrier, recessed into the growth slot will be fabricated. In the interim a thorough leak check of all systems components is underway.

In summary we have achieved a five hour period of growth with replenishment, the longest to date. Further extension of the replenishment period has been hampered primarily by "ice" formation due probably to a-combination of furnace leaks and some particle carryover. We expect to correct these situations shortly and continue to extend the replenishment period.

\subsubsection{Mclt Level Sensing System}

As this quarter ended, the melt level sensor system neared completion. The system uses a low power laser and solid state detector according to a concept devised earlier under this program. ${ }^{2}$ Complete detailed drawings were prepared (See Appendix), components purchased, and all structural parts have been fabricated. Assembly has begun.

The need for maintaining a constant melt level for web growth has previously been established. The two principal parts of a system to maintain a constant melt level are a mechanized polysilicon pellet feeder and a melt level sensor. A mechanized pellet feeder for such a system has previously been developed and is in use. ${ }^{1,2}$ The melt level sensor, when completed, will first be used as a melt level indicator enabling an operator to determine the appropriate rate for feeding polysilicon pellets via the pellet feeder to maintain a constant melt 
level. Ultimately the melt level sensor and the mechanized pellet feeder will be coupled in closed loop control to automatically maintain a constant melt level without operator input.

\subsection{Solar Cell Evaluation}

Nine solar cell processing runs were completed to evaluate silicon web crystals produced this quarter. In a few cases processing faults occurred which compromised the performance data. These crystals have been reprocessed and the data will be reported in the future. In general the characteristics of the web material were similar to those reported before; see e.g. reference 1 . Cell efficiencies ranged from a high of $14.7 \%$ (AMI, AR coated) to a low of $10.2 \%$ with the average at about $13 \%$. As usual, the cell data for each web crystal are compiled in the Appendix.

In addition to the data gathered by means of $10 \mathrm{~mm} \times 10 \mathrm{~mm}$ diagnostic cells described above, processing and evaluation were completed on thirty $16 \times 40 \mathrm{~mm}$ cells which have been sent to J.P.L. as deliverable items under the terms of the contract. All of the crystals used to fabricate these larger cells had been previously characterized by $10 \mathrm{~mm} \times 10 \mathrm{~mm}$ diagnostic cells. It is of some interest to see how well the diagnostic data represents the performance of the larger devices. Table 5 gives a comparison of the two types of cells arranged by crystal. In the case of the diagnostic cells $n_{A R}=1.43 n_{0}$; for the $16 \times 40 \mathrm{~mm}$ cells, $n_{A R}$ is the measured coated efficiency. The same efficiency data is compared graphically in Figure 11. It would appear that the correlation between the two sets of data is generally very good. The occurrence of several outlying points suggests that there is occasional process variation for both types of devices. More generally, however, the agreement is better than $0.5 \%$ in $\eta_{A R}$. One may conclude that the $10 \mathrm{~mm} x 10 \mathrm{~mm}$ diagnostic cells are a valid predictor for the performance of a web crystal as a base material for solar cells, and that excellent cel1 performance is to be expected in the larger area devices. 


\section{TABLE 5}

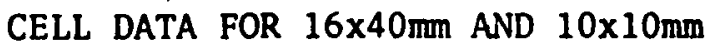
TEST CELLS MADE ON THE SAME WEB CRYSTALS

\begin{tabular}{|c|c|c|c|c|c|}
\hline \multirow[t]{2}{*}{ CRYSTAL } & \multicolumn{2}{|c|}{$16 \times 40 \mathrm{~mm}$ CELLS } & & \multicolumn{2}{|c|}{ 1UXIUMm QUAL CELLS } \\
\hline & $n_{A R}$ & ${ }^{\tau} \mathrm{OCD}$ & & $\mathrm{n}_{\mathrm{AR}}^{\star}$ & ${ }^{\tau} \mathrm{OCD}$ \\
\hline$W 121-1$ & 13.4 & -8 & - & 12.0 & 15 \\
\hline$w 125-1$ & 14.2 & 11 & & 13.7 & 13 \\
\hline W128-2 & 13.3 & 28 & & 13.7 & 32 \\
\hline W135-1 & 13.4 & 8 & & 13.6 & 19 \\
\hline W136-2 & 13.9 & 13 & & 13.7 & 16 \\
\hline W1 38-2 & 13.1 & 9 & & 12.4 & 7 \\
\hline พ139-2 & 13.9 & 9 & & 13.3 & 8 \\
\hline W140-1 & 14.9 & 14 & - & 13.2 & 8 \\
\hline RE78-4. & 12.3 & 3 & & 12.4 & 9 \\
\hline RE 105-3 & 12.9 & 4 & & 13.3 & 0 \\
\hline RE $141-1$ & 13.3 & 5 & & 13.2 & 10 \\
\hline J106-1 & 12,6 & 5 & & 12.0 & 9 \\
\hline J115-3 & 12.0 & 3 & $=$ & 14 & 20 \\
\hline$J 140-3$ & 12.7 & 3. & & 13,3 & 6 \\
\hline
\end{tabular}

$\eta_{A R}$ is the projected value of the coated efficiency

for the $10 \times 10 \mathrm{~mm}$ cells $\left(n_{A R}=1.43 n_{0}\right)$. The $16 \times 40 m n$ cells are coated during fabrication. 


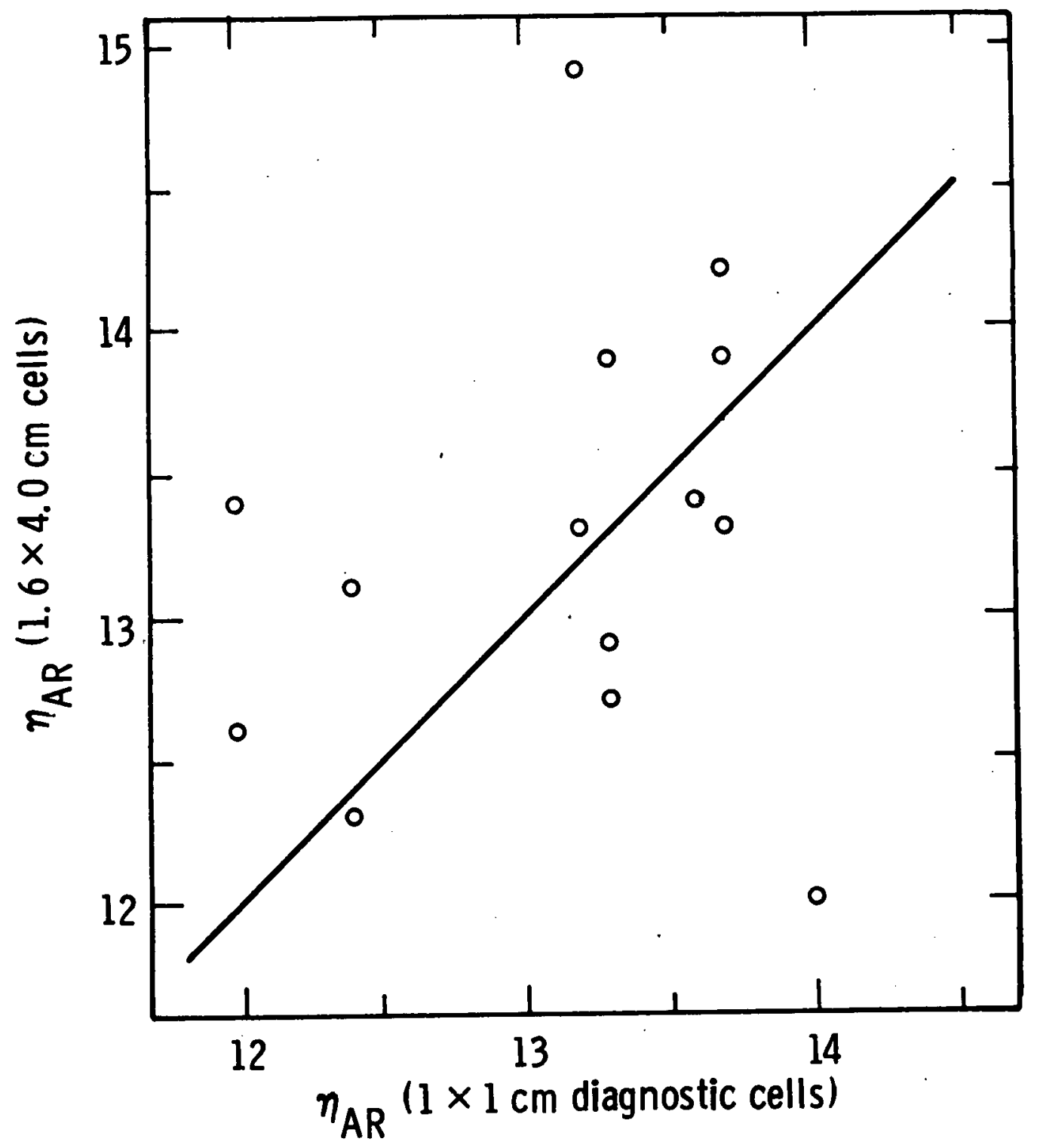

Figure 11. Comparison of cell efficiency for $16 \times 40 \mathrm{~mm}$ and $10 \times 10 \mathrm{~mm}$ solar cells made on the same web crystals. 


\section{CONCLUSIONS}

Major advances in web area output rate and web width were accomplished during the time period covered by this report. An output rate of $27.1 \mathrm{~cm}^{2} / \mathrm{min}$, the highest value to date, was achieved. This is an important result for economic as well as technical reasons. The projected web cost when this output rate is sustained for prolonged operating periods via melt replenishment would fall below the 1986 JPL objective even with $\$ 25 / \mathrm{kg}$ silicon.

The period of simultaneous web growth with replenishment by means of silicon pellets continued to improve. Growth for five hours, more than twice the previously reported high, was accomplished with no feed related problems. We have designed, fabricated and are now assembling the laser meit level sensor system. This system provides a means to monitor the melt level in the growth system in real time so that the silicon consumed during web growth can be replenished at an appropriate rate for steady-state growth.

Thermal measurements coupled with determinations of web thickness and growth velocity have been used to validate the accuracy of the web growth model. Agreement was excellent between the model simulation of the behavior expected from a given susceptor/lid configuration and the experimental data. The model will be used in future work to guide the design of components for enhanced web output rates.

A good correlation was established between the $1 \mathrm{~cm}^{2}$ diagnostic test cells used to characterize material and larger area devices. Web cell efficiencies on experimental crystals produced under a variety of conditions during this program continue to average 12 to $13 \%$ (AM1). 


\section{PLANS FOR FUTURE WORK}

During the coming quarter three major activities will be emphasized: experiments to enhance web width and speed, melt replenishment technology development and the coupling of these two elements to provide for sustained high output rate web growth. Guidance for the design of new components to increase width and speed will come from the recently updated thermal model of the web growth process. We plan to introduce adjustable thermal trimming into the melt replenishment system so that the thermal ambient can be tailored to provide variable heat balance for both growth initiation and steady-state operation.

The melt level sensor will be operated both to test its performance and to provide a control signal for the silicon feed rate during replenishment. 


\section{REFERENCES}

1. C. S. Duncan, et al., Annual Report, Silicon Web Process Development, DOE/JPL-954654-79/2 April (1979).

2. C. S. Duncan, et al., Quarterly Report, Silicon Web Process Development, DOE/JPL-954654-79/3. July (1979).

3. C. S. Duncan, et al., Annual Report, Silicon Web Process Development, DOE/JPL-954654-78/2 April (1978). 


\section{ACKNOWLEDGEMENTS}

We would like to thank P. A. Piotrowski, H. C. Foust, E. P. A. Metz, W. B. Stickel, J. M. Polito, A.M. Stewart, J. P. Fello, and $C . H$. Lynn for their contribuliuns to the web growth studies and P. Rai-Clivulliury, R. B. Campbe11, E. J. Seman, I., B. McNa11y, W. Cifone, D. N. Schmidt, and H. F. Abt for the processing and testing of the web sular cells. 
9. APPENDICES 


\subsection{Growth Run Sumnaries}

Studies designed primarily to enhance web width were conducted in the $\mathrm{J}$-furnace while all melt replenishment experiments were performed in the RE furnace. The major activities in the new WA furnace were shakedown and test of the equipment itself and initiation of studies to optimize web growth velocity for high output rate operation. 
GROWTH RUN SUMMARY

\begin{tabular}{|c|c|c|c|c|c|}
\hline RUN & $\begin{array}{l}\text { NO. OF } \\
\text { CRYSTALS }\end{array}$ & $\begin{array}{l}\text { LENGTH } \\
\text { (cm) }\end{array}$ & $\begin{array}{l}\text { MAX. WIDTH } \\
\text { (mm) }\end{array}$ & $\begin{array}{l}\text { MAX. VELOCITY } \\
(\mathrm{cm} / \mathrm{min})\end{array}$ & DESCRIPTION/RESULT \\
\hline $\mathrm{J}-183$ & 2 & 286 & 38.5 & 1.7 & $\begin{array}{l}\text { Repeat J181 configuration. Early starts tended } \\
\text { to generate lines in crystals. Growth good later. }\end{array}$ \\
\hline $\mathrm{J}-184$ & 3 & 409 & 33.1 & 1.7 & J-181 configuration. Similar to previous run. \\
\hline$J-185$ & 3 & 431 & 33.5 & 1.7 & $\begin{array}{l}\text { J-181 configuration. Good crystal terminated by } \\
\text { pul1 out. }\end{array}$ \\
\hline$J-186$ & 3 & 266 & 28.0 & 1.7 & $\begin{array}{l}\text { To produce lower resistivity material for evaluation, } \\
\left(6 \times 10^{17} \text { total boron) } \mathrm{J}-181 \text { configuration. Crystals }\right. \\
\text { terminated because of degeneration in quality. }\end{array}$ \\
\hline$J-18.7$ & 4 & 513 & 33.4 & 1.6 & $\begin{array}{l}\text { Test new configuration. Insert additional } 0.5 \mathrm{~mm} \\
\text { thick full shield with slight bevel overlap into } \\
\mathrm{J}-181 \text { shield stack. Total } 4 \text { top shields. } 6 \times 10^{17} \\
\text { total boron. Growth behavior generally good. } \\
\text { Crystals terminated by pull out. }\end{array}$ \\
\hline
\end{tabular}

$\mathrm{J}-188$ No significant web production

Repeat J-187 configuration. Most of day spent video taping of growth initiation.

$\begin{array}{ccccc}\stackrel{\mathrm{O}}{\mathrm{J}-189} & 2 & 494 & 36.0 & 5.1 \\ \mathrm{~J}-190 & 5 & 525 & 30.1 & 1.6 \\ \mathrm{~J}-191 & 3 & 378 & 33.9 & 6.6 \\ \mathrm{~J}-192 & 3 & 534 & 36.0 & 5.2 \\ \mathrm{~J}-193 & \text { Not Productive of Web. } & \end{array}$

Repeat J-187configuration. Reached thruput values of 15.8 and $16.6 \mathrm{~cm}^{2} / \mathrm{min}$.

Repeat J-187 configuration. Early crystals terminated by pull out or quality degeneration. Conclude this configuration not improvement over J-181 in terms of width capabilities.

J-181 configuration. Crystal quality poor early, good later in day.

$\mathrm{J}-181$ configuration modified by addition of $0.5 \mathrm{~mm}$ thick shield directly on top. Max thruput of $18.7 \mathrm{~cm}^{2} / \mathrm{min}$.

j-181 configuration. Piece of oxide fell into melt early and attached to crucible wall, causing ice nucleation. 
GRONTH RUN SUMMARY

\begin{tabular}{|c|c|c|c|c|c|}
\hline RUN & $\begin{array}{l}\text { NO. OF } \\
\text { CRYSTALS }\end{array}$ & $\begin{array}{l}\text { LENGTH } \\
\text { (cm) }\end{array}$ & $\begin{array}{l}\text { MAX. WIDTH } \\
\text { (mun) }\end{array}$ & $\begin{array}{l}\text { MAX. VELOCITY } \\
(\mathrm{cm} / \mathrm{min})\end{array}$ & DESCRIPTION/RESULT \\
\hline$J-194$ & 3 & 445 & 30.5 & 1.6 & $\begin{array}{l}\text { J-181 con }=\text { iguration. Crystals terminated by } \\
\text { pul1 out. Attempt was made to minimize under- } \\
\text { cooling during growth. }\end{array}$ \\
\hline $\mathrm{J}-195$ & 3 & 499 & 35.8 & 6.0 & $J-181$ configuration. Max. thruput $21.5 \mathrm{~cm}^{2} / \mathrm{min}$. \\
\hline $\mathrm{J}-196$ & 2 & 421 & 35.7 & 7.6 & $\begin{array}{l}\mathrm{J}-181 \text { configuration with additional thin top shield. } \\
\text { Reached record thruput of } 27.1 \mathrm{~cm}^{2} / \mathrm{min} \text {. }\end{array}$ \\
\hline
\end{tabular}


GROWTH RIIN SIMMARY

\begin{tabular}{|c|c|c|c|c|}
\hline RIJN & $\begin{array}{l}\text { NO. OF } \\
\text { C.RYSTAI.S }\end{array}$ & $\begin{array}{l}\text { I.EN(BIII) } \\
(\mathrm{cm})\end{array}$ & $\begin{array}{c}\text { Max. WIDTHI } \\
(\mathrm{mm})\end{array}$ & $\begin{array}{l}M A X . \text { VI:I.OCITY } \\
(\mathrm{cm} / \mathrm{min})\end{array}$ \\
\hline
\end{tabular}

$1-197$

9.7

3.3

?urpose: Tu measure 1 id and top shid!d temperatures of J-18l confienrapion. See text for results. lhichues velocity data. Doped to 22 ohm-cin.

$\begin{array}{llll}1-198 & 4.86 & 20.8\end{array}$

$j-199$

3

200

19.9

$J-200$

2

$\stackrel{1}{\text { G }}$

$J-201$

4

$J-202$

3

2

$\stackrel{N}{\stackrel{N}{\Xi}}$

$. \mathrm{J}-204$

2

$4: 11$

410

.. .205

Not Proluctive of Wol

$.1-206$

$\underline{2}$

167

24.1

3.3

rest J-181 configuration with addition of 0 bim thich shield spaced $1.5 \mathrm{~mm}$ above upper thick shield. inped to ، 2 ohm-cm. Thickness-velocity data. Cirowth lechavior gencrally poor.

3.3

Repeat J-198, with spacing of top most shield increascd to 4.5mm. Thickness velocity data. Difficult to start and grow.

3.3 J-181 sonfiguration. New width record. Thruput rate of $15.8 \mathrm{~cm}^{2}$ inin.

2.8 .I-181 configuration. Some difficulty starting growth carly in day.

$1.8 \mathrm{~J}-181$ configuration. Dendrites somewhat choppy.

1.7

J-181 configuration. Some starting difficulties early gond growth during afternoon.

Test modification of $J-181$ configuration. Niddle Tol shjeld slitted around peripherv to limit r.f. coupling. (Sce Text)

1.6 Another J-181 modification with slitted shicld on ton. Doped to $\sim 2 \mathrm{ohm}-\mathrm{cm}$. Crystals terminated by pullouts.

Repeat J-205. Melt very unstable for no apparent reason.

3.3 Repeat .3-205 configuration. Thickness-velocity data. Coil raised to improve dendrite penetration. Improved growth hehavior, but crystal terminated when reel tape tension wire failed. 


\section{GROWTH RUN SUMMARY}

$\begin{array}{llcccc}\text { NO. OF } & \text { LENGTH } & \text { MAX. WIDTH } & \text { MAX. VELOCITY } & (\mathrm{cm} / \mathrm{min} ! & \text { DESCRIPTION/RESULT }\end{array}$

\begin{tabular}{|c|c|c|c|c|c|}
\hline $\mathrm{J} 208$ & 2 & $4 ? 0$ & 33.7 & 1.6 & $\begin{array}{l}\mathrm{J}-181 \text { configuration. Radiation shields below susceptor } \\
\text { replaced. Nominal } 175 \mathrm{gm} \text { melt as opposed to standard } \\
185 \text { gms to start at slight } 1 \text { l lower melt level. Generally } \\
\text { good growth behavior. }\end{array}$ \\
\hline
\end{tabular}

$\begin{aligned} & \text { slitted around periphery. To minimize } r . f . \text { coupling and } \\ & \text { thus reduce temperature. Jery stable growth. }\end{aligned}$

J-210 $3 \quad 6 \Xi 6^{\circ} \quad 38 . \dot{4}^{\circ} \quad 1.6 \quad$ Modification of J-181 configuration, extra top shield,

upper Two slitted ta reduce r.f. coupling. Good growth behavior.

$\mathrm{J}-211 \quad 5 \quad 350 \quad 24$.

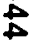

$\begin{array}{lllll}\mathrm{J}-212 & 3 & 556 & 32.7 & 5.0 \\ \mathrm{~J}-213 & 4 & 432 & 32.0 & 5.2 \\ \mathrm{~J}-214 & 2 & 220 & 18.5 & 5.3\end{array}$

$\mathrm{J}-215$ No significant web production

Repeat J-210 configuration. Thickness-velocity data. Growth behavior pocr relative to $\mathrm{J}-210$. After run, 1t was discovered that $S 1$ melt had not wetted one end of crucible, and pulled away further as run progressed.

Repeat J-210 conflguration, except starting melt increased to $185 \mathrm{gms}$. Thickness velocity data. Reached $16.5 \mathrm{~cm} / \mathrm{min}$ thruput.

.2 Repeat J-210 configuraticn. Thickness-velocity data early and late in day. $16.6 \mathrm{~cm}^{2} / \mathrm{min}$ max. Thruput.

Test different to shield configuration. J-181 11d with RE-1 type shields, except upper slitted. Thicknessvelocity data. Instable melt. Poor growth behavior.

J-210 configuration with 11 d and topmost shield instrumented. Melt unstable. Thermocoufle feed through evidently leaked, causing partial oxidation of side shields. 


\section{GROWTH RUN SUMMARY}

$\begin{array}{llccc}\text { NO. OF } & \text { LENGTH } & \text { MAX, WIDTH } & \\ \text { RUN } & \text { CRYSTALS } & (\mathrm{cm}) & (\mathrm{mm}) & \text { DESCRIPTION/RESULT }\end{array}$

$\begin{array}{llll}\text { RE165 } 351 & 18.6 \quad \begin{array}{l}\text { Molybdenum blocks were placed on the ends of the wide growth } \\ \text { slot to evaluate for use in width control. Oxide grew on the } \\ \text { blocks and caused ice throughout the run. }\end{array}\end{array}$

RE166

2

RE167

3

RE,168

2

i

RE169 NONPRODUCTIVE

RE170

1

105

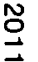

RE171

402

RE172

slot to evaluate for use in width control.

18.6

This run was a repeat of the set up of RE165: Although oxide grew on the blocks, ice was not a problem. One of this run's crystals held a width within $2 \mathrm{~mm}$ for $90 \mathrm{~cm}$, a positive result for width control.

23.2 This was another run 1ike RE165. Again oxide on the blocks caused ice and prevented good crystal growth.

19.0 To try to keep the 1ids blocks hotter, and oxide free, blocks were placed on the shields above the other blocks. The result was oxide along the slot of the shield as well as on the moly blocks.

Run aborted because of water pressure problems.

Wide grow lid and shields, with feeding. The feed tube was colled to slow the pellets, to decrease the impact wave. Ice occurred when feeding was tried.

A lid with a long straight slot (no dogbone) was tried with the moly blocks to see if the gas flow would be sufficiently different. However, oxide on the blocks was as bad as with the dogbone lid.

Wide grow lid and shields for feeding, using a solid end shield on feed side. Feeding resulted in ice; experiment ended when pellets became stuck in feed coll. Enough web was pulled out that the melt shifted near the end of the day. Incomplete wetting of the quartz was evident in the feed chamber. 


\begin{tabular}{|c|c|c|c|c|}
\hline RUN & $\begin{array}{l}\text { NO. OF } \\
\text { CRYSTALS }\end{array}$ & $\begin{array}{l}\text { LENGTH } \\
(\mathrm{cm})\end{array}$ & $\underset{(\mathrm{mm})}{\operatorname{MAX} . \text { WIDTH }}$ & DESCRİPTION/RESULT \\
\hline RE173 & 1 & 147 & 29.4 & $\begin{array}{l}\text { Set up like RE172, using a different feed coll. A large amount } \\
\text { of silicon was pulled before the recorded crystal was grown. This } \\
\text { was necessary because the melt level was higher than normal, due to } \\
\text { a failure of wetting in the feed chanber. Suspected cause: the } \\
\text { arrangement of the polysiliccn in the crucible. }\end{array}$ \\
\hline RE174 & 1 & 92 & & $\begin{array}{l}\text { Set up like RE172, except using the perforated end shield. The } \\
\text { aspirator flow was varied thraughout the day as about } 10 \text { crystals } \\
\text { were started. This was done to find the flow which would be the } \\
\text { most effective in the prevention of ice. }\end{array}$ \\
\hline RE175 & 2 & 393 & 41.5 & $\begin{array}{l}\text { Wide growth slot in lid and shield. The lid had slots milled into } \\
\text { the bottom. These slots act as asfirators, allowing the silicon } \\
\text { oxide an alternative to the growth slot as an exit from the crucible } \\
\text { region. With this lid the oxide deposited on the web was largely } \\
\text { a hard oxide, but the bottom of the lid was perfectly clean. }\end{array}$ \\
\hline
\end{tabular}


GROWTH RUN SUMMARY

\begin{tabular}{|c|c|c|c|c|}
\hline RUN & $\begin{array}{l}\text { NO. OF } \\
\text { CRYSTALS }\end{array}$ & $\begin{array}{l}\text { LENCTHI } \\
\text { (cm) }\end{array}$ & $\begin{array}{l}\text { MAX. WIDTH } \\
(\mathrm{mm})\end{array}$ & DI:SCRI PTION/RESULT \\
\hline$R E-176$ & 7 & 546 & $3 \overline{2} .6$ & $\begin{array}{l}\text { J-181 configuration for feeding, perforated shield on left end. } \\
\text { Oxide on the lid was the most significant problem, preventing } \\
\text { long growth periods. One } 40 \mathrm{~min} \text {. feed period was achieved } \\
\text { before the oxide caused ice. }\end{array}$ \\
\hline RE: -177 & 2 & 231 & 28.2 & $\begin{array}{l}\text { Set up like RF-176. Oxide again was a problem, but not as much } \\
\text { as in RE-176. Ice occurred several times while feeding, hut } \\
\text { generally these particles could be melted while crystal growth } \\
\text { cont inued on one crystal } 1 \mathrm{hr} 23 \mathrm{~min} \text {. of feeding was achieved. } \\
\text { before ice ended growth. }\end{array}$ \\
\hline
\end{tabular}

$\begin{array}{llll}\text { RE- } 178 & 1 & 102 & 23.1\end{array}$

Set up 1ike RE-176. There was no oxide on the lid, but ice was a problem. Feeding was not practicable this run because the feed end of the crucible had "dewetted" and held no silicon.

An error in the furnace setup resulted in conditions that made crystal growth impossible.

RE:- : 80
3
Set up like RE176. The thermal profile was peculiar; the ends of the crucible seemed colder than normal, relative to the center temperature.

J-181 lid and shields for feeding; solid shield on feed end of susceptor to increase the end temperature. There was some oxide on the lid in the beginning of the run, but it was a temporary problem. When feeding was tried, this proved to be the most successful run yet. No feed related problems were encountered all day. Of the crystals grown, the longest grew for $2 \mathrm{hr}$. $23 \mathrm{~min}$. with feeding. (Over 5 hours of feed time, 3 crystals were obtained without ice.)

Repeat setup of RE181. This run was not successful; the feed chamber had dewetted and so held no silicon except the pellets which were added later. 


$\begin{array}{llccc} & \text { NO. OF } & \text { LENGTH } & \text { MAX. WIDTH } & \\ \text { RUN } & \text { CRYSTALS } & (\mathrm{cm}) & (\mathrm{mm}) & \text { DESCRIPTION/RESULT }\end{array}$

\begin{tabular}{|c|c|c|c|c|}
\hline RE - 183 & 1 & 170 & 33.6 & $\begin{array}{l}\text { Repeat set-up of RE181. A different coil position was tried in } \\
\text { the meltdown, but again the feed chamber was empty. }\end{array}$ \\
\hline
\end{tabular}

RE-184 Nonproductive of Web

Repeat setup of RE181. A more extreme coil position was tried, successfully wetting the feed chamber of the crucible. However the other end of the crucible did nct wet properly, and no good crystals were obtained.

RE-185 223

RE-186

1

106

20.0

Repeat lid and shield of RE181. The barrier used had a $3 \mathrm{~mm}$ ridge along the bottom of the crucible with a $3 \mathrm{~mm}$ gap above the ridge. The furnace components were slightly oxidized during the run, affecting the thermal gradients. Ice occurred throughout the run.

J-181 lid configuration perforated end shield; ice occurred with feeding. 


\begin{tabular}{|c|c|c|c|c|}
\hline RUN & $\begin{array}{l}\text { NO. OF } \\
\text { CRYSTALS }\end{array}$ & $\begin{array}{l}\text { LENCTH } \\
(\mathrm{cm})\end{array}$ & $\begin{array}{l}\text { MAX. WIDTH } \\
(\mathrm{mm})\end{array}$ & LESCRIPTION/RESUIT \\
\hline RE188 & 3 & 355 & & $\mathrm{~J}-181$ 1id and shields, not set up for feeding. \\
\hline RE189 & $\because \because$ & 204 & 21.8 & $\begin{array}{l}\text { J-181 lid and shields; solid end shield; "fence" barrier. } \\
\text { Misalignment of feed tube resulted in ice when pellets rolled } \\
\text { across the lid into the growth slot. Three crystals were grown } \\
\text { for periods of up to } 1 \mathrm{hr} 15 \mathrm{~min} \text {. with feeding with no other ice } \\
\text { problems. }\end{array}$ \\
\hline RE190 & 2 & & 23.6 & $\begin{array}{l}\mathrm{J}-181 \text { 11d and shields, solid end shield. Ice was a problem in } \\
\text { this run; the cause is uncertain. }\end{array}$ \\
\hline RE191 & 1 & 90 & 22.2 & $\begin{array}{l}\text { J-181 Iid and shields; solid end shield. Ice was a problem with } \\
\text { and without feeding. }\end{array}$ \\
\hline
\end{tabular}

RE192 Nonproductive of Web

$\stackrel{8}{0}$

RE193

1

96

$\stackrel{?}{\Xi}$

RE195 Nonproductive of Web

RE196 Nonproductive of Web

RE197 Nonproductive of Web
J-181 1id and shields for feeding; solid end shield. Ice was a problem with and without feeding.

23.1 J-181 lid and shields for feeding; solid end shield. Ice was a continuous problem; there was evidence of spalling on the lid.

J-181 lid and shield. This was not a feed run. Ice was a problem, generally occuring; within an hour after a crystal was begun. Again there was evidence of spalling, despite the heavy sand blasting the lid recelved before the run.

J-181 1id with slotted bottom. Continual oxide growth on the 11d prevented crystal growth. The probable cause of the oxide was an improperly cleaning of the 1 id.

J-181 11d for feeding, solid end shield. Whenever feeding was tried ice occurred. From the shape of the ice and from the varled times before ice appeared, oxide particles were the probable cause.

J-181 1id with milled bottom. Ice was again a problem. 


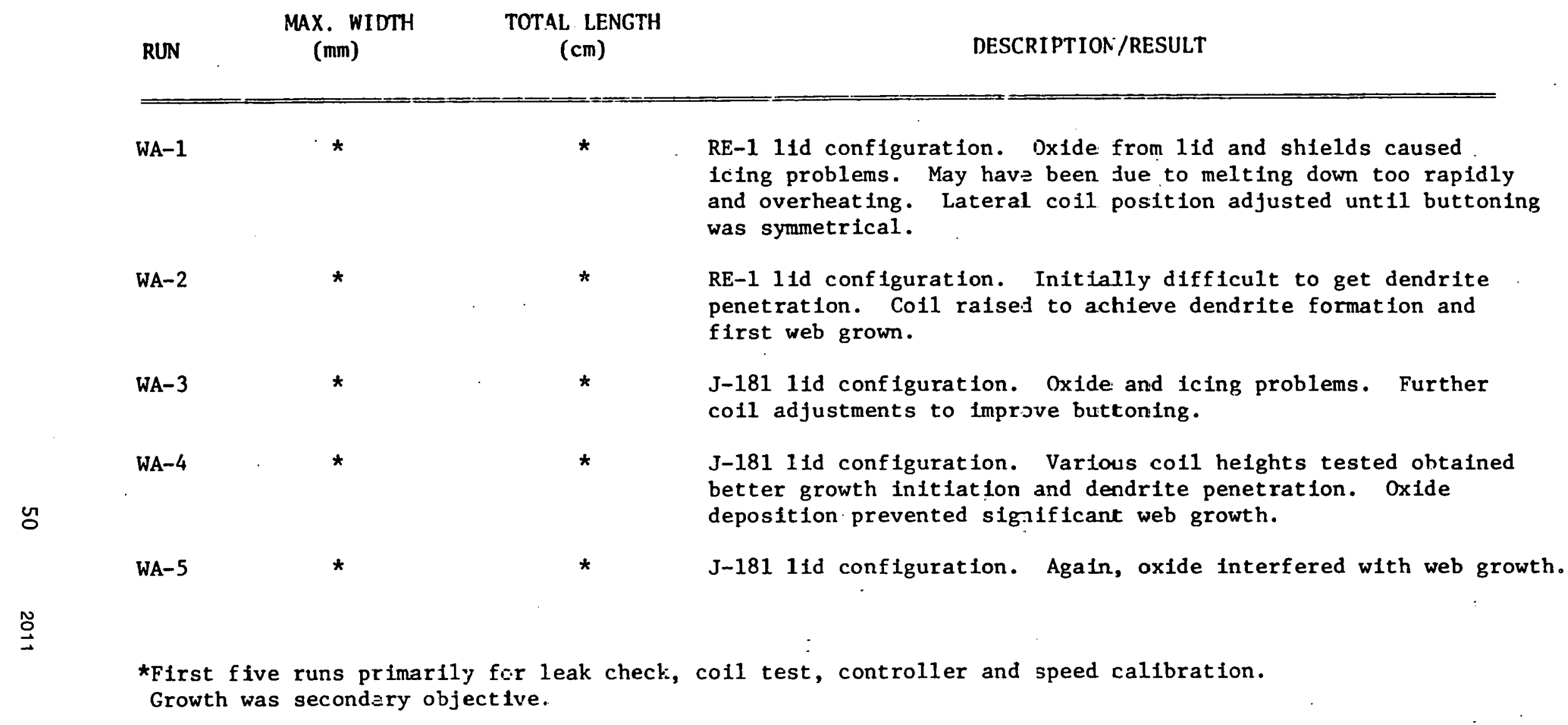


RROWTH RIIN SUMMARY

MIN W. WIDTH TOTAL LENGTII
$(\mathrm{cm})$

WA- 6

WA -7

WA- 8

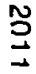

WA -10

Not Productive of Web

WA- 11

112

Not Productive of Web
Growing with vented lid in $J 181$ configuration, to help eliminate oxide problems. Oxide was not a problem and growth was good. There was some polycrystalline growth and choppy dendrites until the melt was lowered by about 10 grams. Coil was adjusted for more symmetric growth.

Using standard J181 configuration with a slower melt down to help prevent oxide development. This run was free of oxide and growth was good. Some additional coil movements were made to improve button symmetry and dendrite penetration.

Standard J-181 configuration using normal melt down procedures. The more rapid melt down previously used seemed to be a cause of oxide formation. No long pieces were grown because of oxide falling in the melt causing ice.

Repeat WA-7 using slow me1t down to prevent oxide development. This run was again free of oxide, and oxide formation appears to be definitely related in part to melt down procedure. Growth was good with very few adjustments being required.

J-181 configuration being used for pull speed calibration. A more rapid melt down was used which resulted in oxide formation again. Future runs should be made with the slower melt down proredure. oxide formation prohibited growth, but pull speed calibration was made, as intended.

Repeat WA-10 run, repeating pull speed calibration. Problems with melt down and lid preparation resulted in some oxide. Polycrystalline growth was a problem early in the run. Past experience suggests a lower starting melt weight will offset this difficulty. 
CRONTH RUN SUMMARY

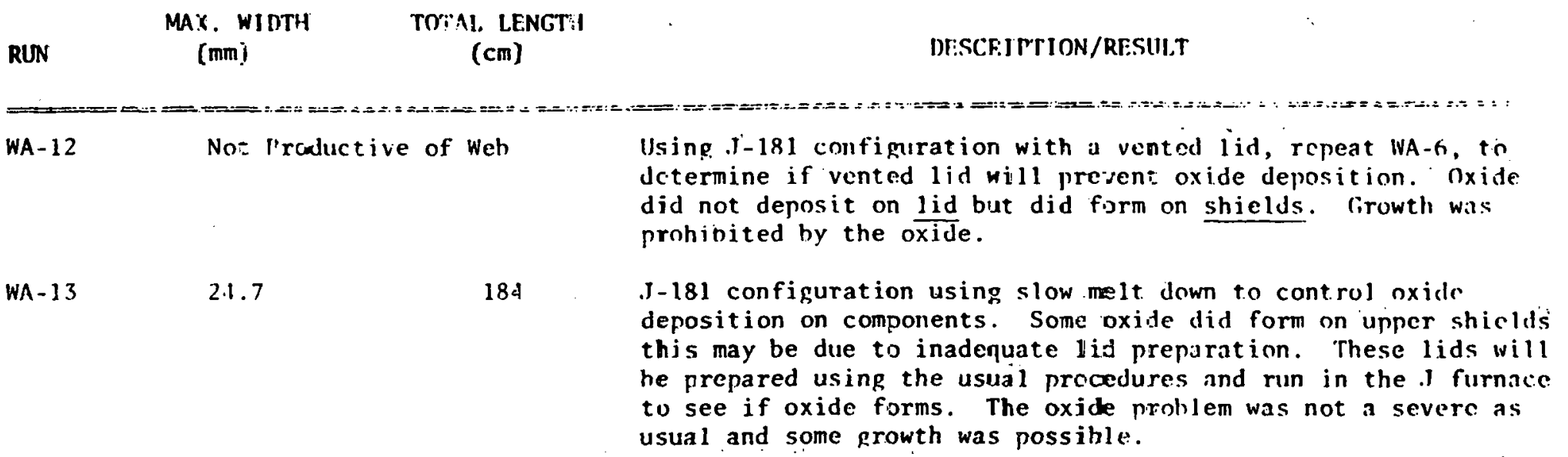




RUN $\begin{gathered}(\mathrm{cm}) \\ \text { DESCRIPTION/RESULT }\end{gathered}$

WA-14 $\quad 3.0 \mathrm{~cm}$

Not Product1ve of Web

WA-15

WA-16

$3.4 \mathrm{~cm}$

WA-17

$3.3 \mathrm{~cm}$

$150 \mathrm{~cm}$

un
WA-19 Not Productive of Web
$109 \mathrm{~cm}$.

J-181 configuration with $1 / 16^{\prime \prime}$ raised top shleld. Clean and oxide free, raising shleld helped prevent oxide. Problems were with polycrystalline growth, may be due to high argon flow rates.

Repeat WA-14 configuration. Clean and oxide free, raised shield appears to eliminate oxide. Lower argon flow appears to have corrected polygrowth problem, except at higher speeds.

$160 \mathrm{~cm}$.

epeat WA-14, this run was clean and oxide free. Thickness velocity data for the. J181 configuration was obtained. The melt weight was increased again to 185 grams but polycrystalline growth resulted early in the run.

This run used a $30^{\circ}$ beveled 1 .1d with a J181 shlelding configuration to improve the radiation losses from the web. Growth was good and the run was clean. Thickness velocity data was taken and thickness was increased by $20 \%$ for a given pull speed as compared to the standard $\mathrm{J}-181$ 11d.

Repeating WA-17 configuration to get additional thickness-velocity data on the new 11d. This run was again clean and oxtde free. Sever short crystals were grown and thickness data recorded. The higher 1 melt level is still resulting in polycrystal line growth early in the run.

Repeating WA-17, thickness velocity data was recorded for several short crystals and the thickness is still greater as compared to the standard J-181 configuration.

WA-20 $\quad 3.8 \mathrm{~cm} \quad 182 \mathrm{~cm}$

Repeat WA-14 using J-181 configuration to get thickness-velocity data. This run was clean and free of oxide. 


\section{AVERAGED SOLAR CELL DATA FOR WEB CRYSTALS}

The tables in this appendix give the averaged solar cell performance for cells fabricated from the crystals listed. Each entry in the table represents the average value for approximately four cells. Measurement conditions were a simulation of an AM1 illumination at a power density of $91.6 \mathrm{~mW} / \mathrm{cm}^{2}$ as determined by a standardized solar cell. The cells were nominally $10 \times 10 \mathrm{~mm}$ square. (actual area $1.032 \mathrm{~cm}^{2}$ ), and had an active area of about $92.5 \%$. The cell efficiency with an antireflective coating $n_{A R}$, is an estimated value based on an average improvement factor of 1.43 , typical of the results we obtain in practice with a $\mathrm{TiO}_{2}-\mathrm{SiO}_{2}$ coating. 
SUMMARY OF DIAGNOSTIC SOLAR CELL DATA

J-, RE-, and W-Crystals

\begin{tabular}{|c|c|c|c|c|c|c|c|c|c|c|}
\hline Crystal & Run & $I_{\mathrm{mAC}}$ & $\begin{array}{l}\mathrm{V}_{\mathrm{OC}} \\
\text { volt }\end{array}$ & $\mathrm{FF}$ & $n_{8}$ & $\underset{\%}{n_{A}}$ & ${ }_{\mu \mathrm{S}}^{\text {TOCD }}$ & $\stackrel{\rho}{\Omega-\mathrm{cm}}$ & \multicolumn{2}{|c|}{ NOTES } \\
\hline $3176-2.6$ & WQ30 & 21.1 & .534 & .752 & 9.0 & 12.9 & 6.5 & 8.0 & & \\
\hline $\mathrm{J} 181-2.4$ & WQ35 & 21.7 & .55 & .755 & 9.6 & 13.7 & 11.1 & 8.3 & & \\
\hline $\mathrm{J} 182-2.4$ & WQ31 & 18.4 & .503 & .728 & 7.1 & 10.2 & 1.0 & 8.3 & & \\
\hline $\mathrm{J} 183-2.1$ & WQ31 & 19.2 & .511 & .740 & 7.7 & 11.0 & 1.4 & 8.3 & & \\
\hline $\mathrm{J} 185-1.3$ & WQ33 & 22.6 & .522 & .695 & 8.7 & 12.4 & 4.8 & 8.4 & & \\
\hline$J 185-2.4$ & WQ33 & 22.3 & .506 & .712 & 8.5 & 12.2 & 3.3 & 8.0 & & \\
\hline $\mathrm{J} 187-2.3$ & WQ33 & 21.8 & .547 & .750 & 9.4 & 13.4 & 4.6 & 3.1 & & . \\
\hline $\mathrm{J} 187-3.4$ & WQ33 & 22.1 & .555 & .750 & 9.7 & 13.9 & 4.8 & 2.9 & & \\
\hline $\mathrm{J} 19 \mathrm{l}-2.3$ & WQ35 & 21.6 & .526 & .737 & 8.9 & 12.7 & 2.8 & 8.9 & & \\
\hline J194-3.4 & WQ35 & 22.6 & .543 & .748 & 9.4 & 13.4 & 10.6 & 12.4 & & \\
\hline J197-2. 2 & WQ36 & 20.8 & .558 & .723 & 8.9 & 12.7 & 2.4 & 1.4 & & \\
\hline $\mathrm{J} 198-2.5$ & WQ38 & 20.7 & .556 & .760 & 9.3 & 13.3 & 2.1 & 1.5 & . & \\
\hline$J 200-2.5$ & WQ36 & 21.2 & .508 & .730 & 8.3 & 11.9 & .3 & 9.1 & & \\
\hline $\mathrm{J} 202-3.5$ & WQ37 & $21: 2$ & .531 & .769 & 9.2 & 13.2 & 3.1 & 8.6 & & \\
\hline $\mathrm{J} 203-2.5$ & WQ37 & 20.9 & .522 & .757 & 8.7 & 12.4 & 2.7 & 11.9 & & \\
\hline J204-1.5 & WQ37 & 20.6 & .517 & .759 & 8.5 & 12.2 & 2.2 & 11.5 & & \\
\hline $\mathrm{J} 204-2.5$ & WQ37 & 20.2 & .504 & .717 & 7.7 & 11.0 & 1.2 & 12.2 & & \\
\hline $\mathrm{J} 205-3.3$ & WQ38 & 18.1 & .523 & .753 & 7.5 & 10.7 & .8 & 1.6 & & \\
\hline RE 155- 1 & WQ30 & 21.5 & .531 & .727 & 8.8 & 12.6 & 6.2 & 8.1 & & \\
\hline RE155- 2 & WQ30 & 21.1 & .540 & .729 & 8.8 & 12.6 & 9.0 & 8.4 & & \\
\hline $\operatorname{RE} 157-1.3$ & WQ30 & 21.0 & .534 & .746 & 8.9 & 12.7 & 7.9 & 8.1 & & . \\
\hline RE $161-1.6$ & WQ35 & 22.4 & .558 & .775 & 10.3 & 14.7 & 10.3 & 7.3 & Feed & Expt. \\
\hline RE175-2.5 & WQ34 & 20.7 & .521 & .749 & 8.5 & 12.2 & 1.7 & 7.0 & & \\
\hline $\mathrm{RE} 177=2.2$ & WQ36 & 21.6 & .518 & $: 719$ & 8.5 & 13.3 & 3.1 & 6.8 & & \\
\hline RE 183-1.4 & WQ37 & 20.3 & .527 & .763 & 8.6 & 12.3 & 1.2 & 12.2 & & \\
\hline W180-3.7 & WQ35 & 18.5 & .589 & .777 & 9.0 & 12.9 & 1.3 & 0.3 & & \\
\hline
\end{tabular}


9.3 Updated Program P1an 
9.3.1

MILESTONE CHART

JPL CONTRACT 954654

PHASE III

\begin{tabular}{|c|c|c|c|c|c|c|c|c|c|c|c|c|c|c|c|c|c|c|}
\hline \multirow{2}{*}{\multicolumn{2}{|c|}{ TASKS/MI LESTONES }} & \multicolumn{9}{|c|}{1979} & \multicolumn{8}{|c|}{1980} \\
\hline & & A & $M$ & $\mathrm{~J}$ & $\mathbf{J}$ & $A$ & s) & $\mathbf{0}$ & $\mathbf{N}$ & D & $\mathrm{s}$ & $\mathbf{F}$ & M & A & M & J & $\mathbf{J}$ & A \\
\hline 1. & $\begin{array}{l}\text { Develop Melt Replenishment (MR) System } \\
\text { With Liquid Level Sensor }\end{array}$ & & & & & & & & & & & & & & & & & \\
\hline 2. & $\begin{array}{l}\text { Develop Advanced Thermal Trimming With } \\
\text { MR to Grow Wide Low Stress Webs at } \\
\text { High Speed }\end{array}$ & & & & & & & & & & & & & & & & & \\
\hline 3. & $\begin{array}{l}\text { Combine the Developments of } 1 \frac{1}{\text { and }} 2 \text {. } \\
\text { Demonstrate Repeatable } 25 \mathrm{~cm}^{2} / \mathrm{min} \\
\text { Growth Output Rate. }\end{array}$ & & & & & & & & & & & $\Delta$ & & & & & & \\
\hline 4. & $\begin{array}{l}\text { Develop Closed Loop Controls for Semi- } \\
\text { Automated (SA) Web Growth }\end{array}$ & & & & & & & & & & & م & & & & & & \\
\hline 5. & $\begin{array}{l}\text { Operate the SA Web Growth and Evaluate } \\
\text { Its Feasibility to Attain Throughput } \\
\text { Goal }\end{array}$ & & & & & & & & & & & & & & & & & \\
\hline 6. & $\begin{array}{l}\text { Prepare a Complete Design of a } \\
\text { Totally Automated Experimental Web } \\
\text { Growth Machine with all Functional } \\
\text { Feature Assumed in Economic Analysis }\end{array}$ & & & & & & & & & & & & & & & & & \\
\hline 7. & $\begin{array}{l}\text { Perform Characterization of Selected } \\
\text { Web Samples and Demonstrate Solar } \\
\text { Cells with Efficiency of } 158 \text { AMI }\end{array}$ & & & & & & & & & & & & & & & & & \\
\hline 8. & $\begin{array}{l}\text { Provide a Minimum of } 10 \text { Solar Cells } \\
\text { per month, with Data, Fabricated } \\
\text { From Representative Web Ribbons }\end{array}$ & & & & & & & & & & & & & & & & & \\
\hline 9. & $\begin{array}{l}\text { Provide an Average of } 2 \text { Meters per } \\
\text { Month of Web Samples of } 2.5 \mathrm{~cm} \text { or } \\
\text { Greater Width }\end{array}$ & & & & & & & & & & & & & & & & & \\
\hline 10. & $\begin{array}{l}\text { Update Economic Analysis not } \\
\text { Later Than }\end{array}$ & & & & & & & & $\Delta$ & & $\Delta$ & & & $\Delta$ & & & & \\
\hline 11. & $\begin{array}{l}\text { Provide Personnel to Support } \\
\text { Required Meetings }\end{array}$ & & & & & & & & & & & & & & & & & \\
\hline 12. & Provide Documentation & & & & & & & & & & & & & & & & & \\
\hline
\end{tabular}




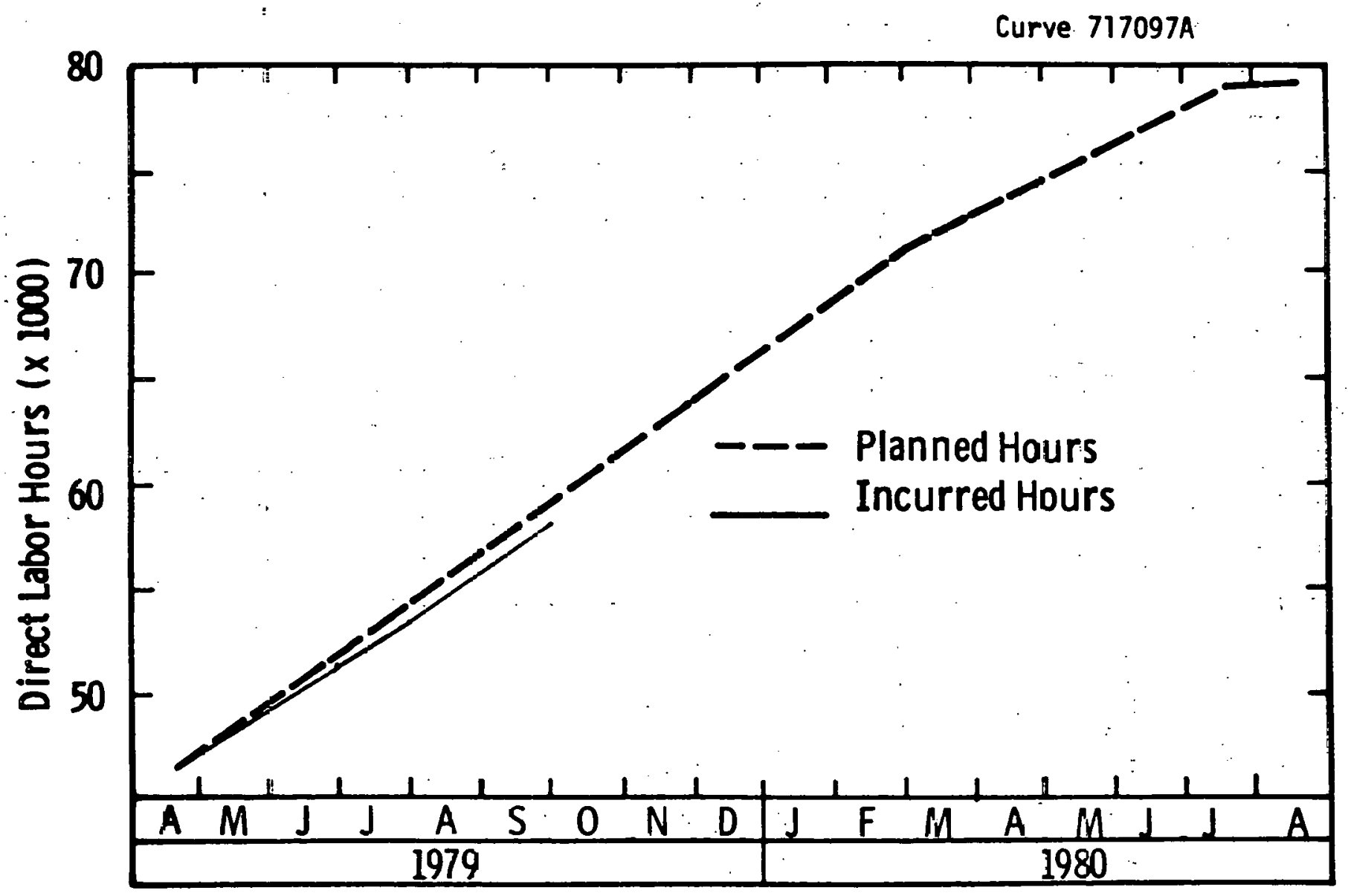

9.3.2 Program Labor Summary JPL 954654, Pha se III 
Curve 717096A

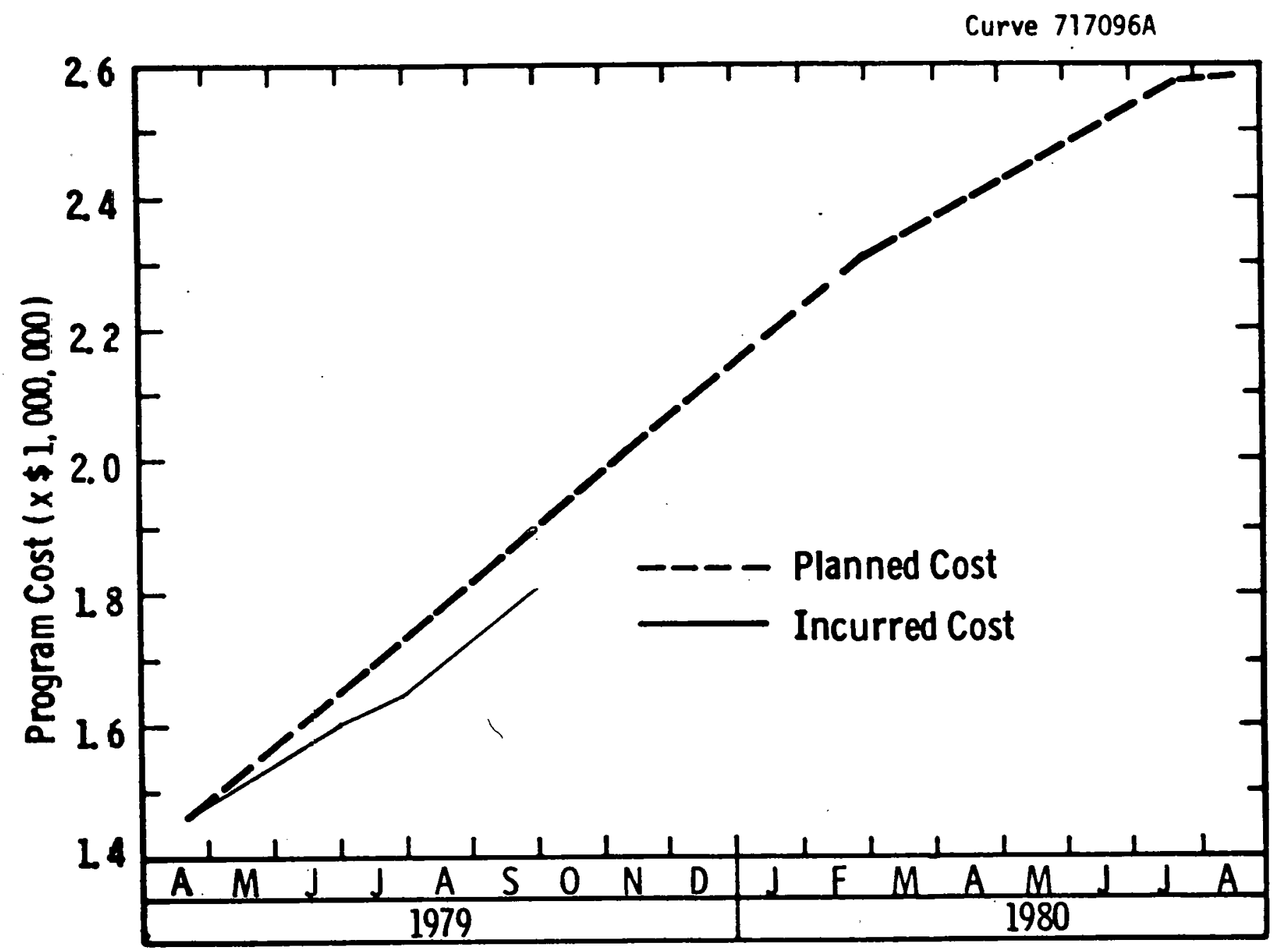

9.3.3 'Program Cost Summary JPL 954654. Phase III 


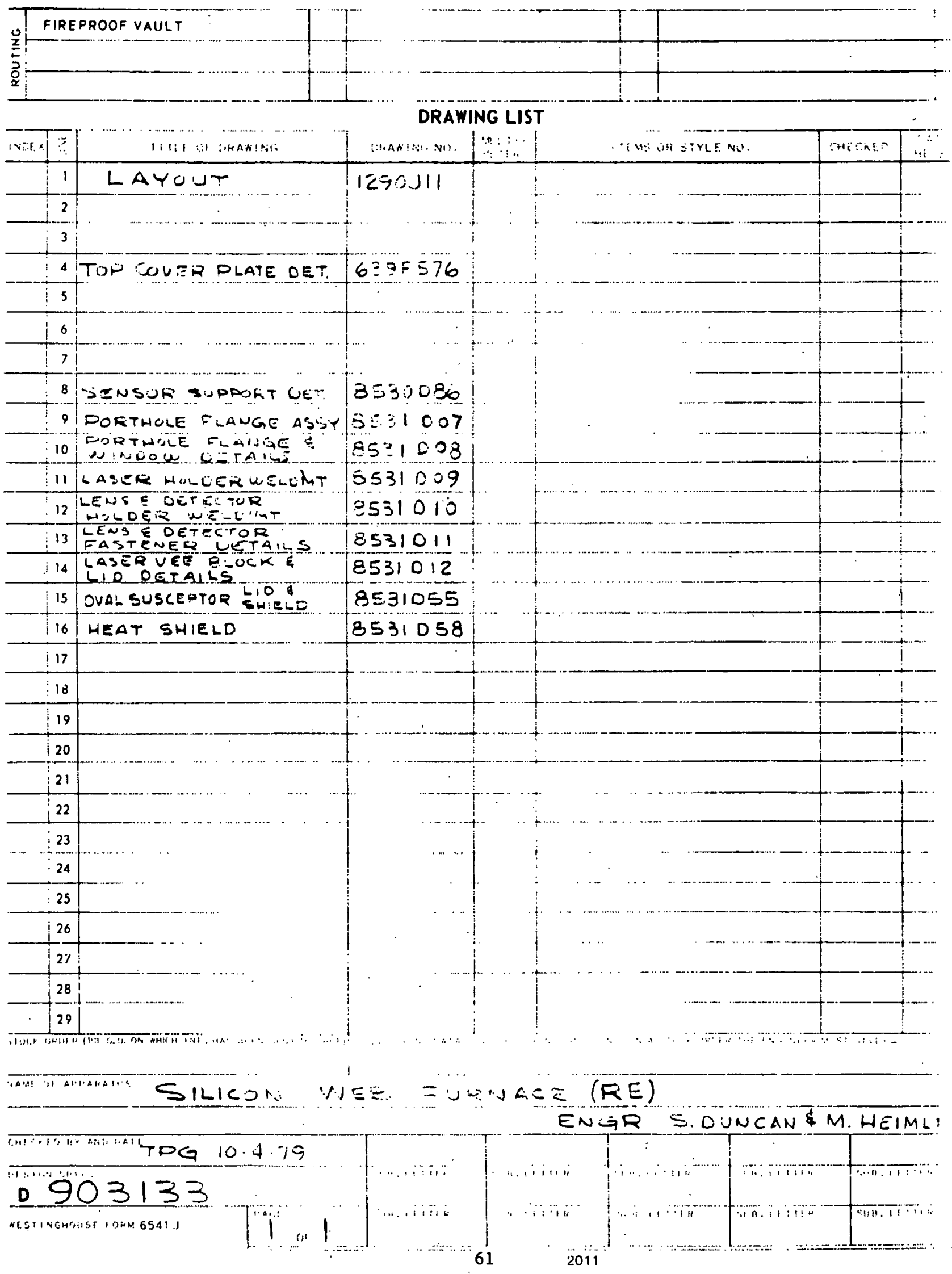




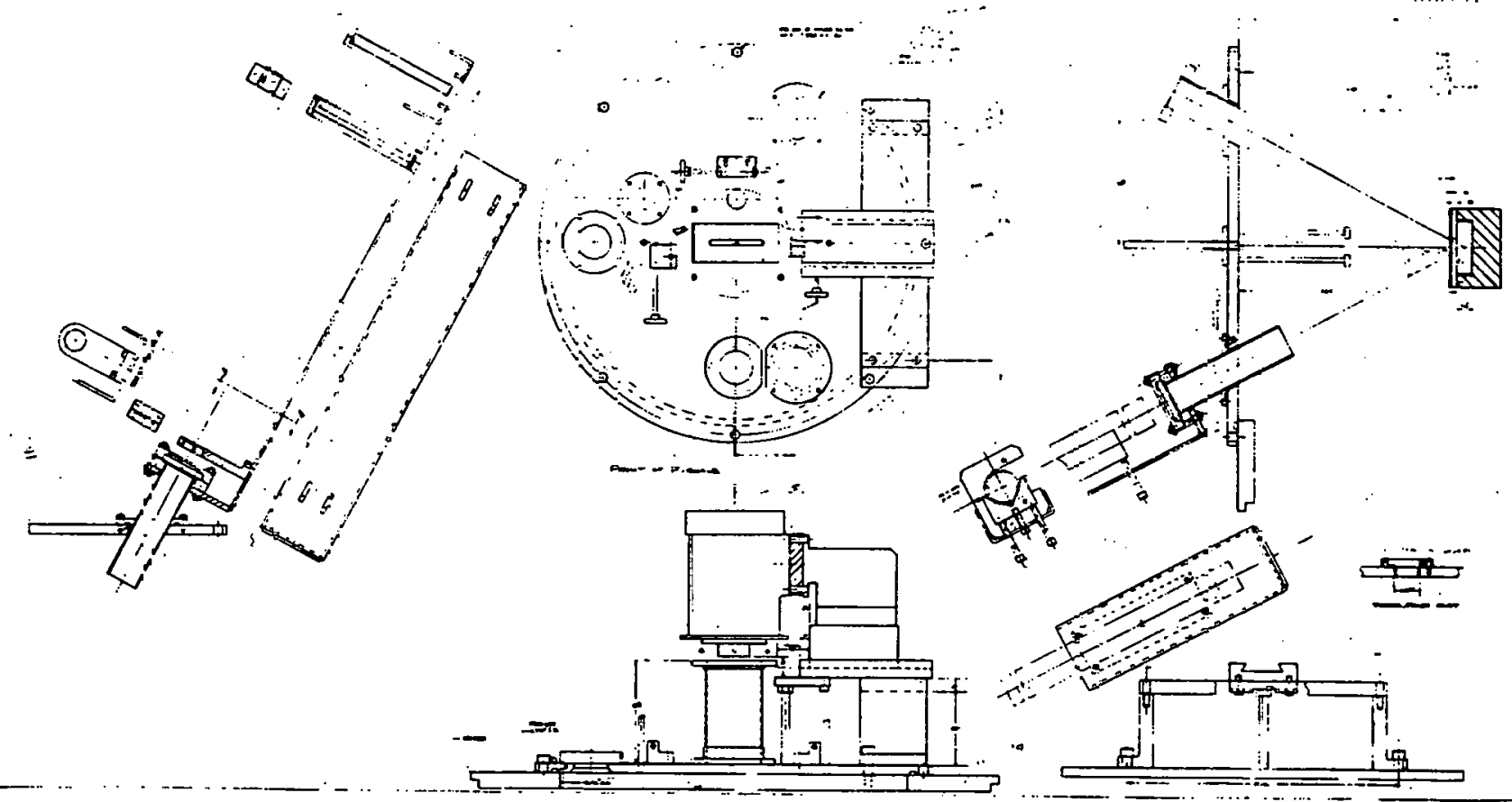




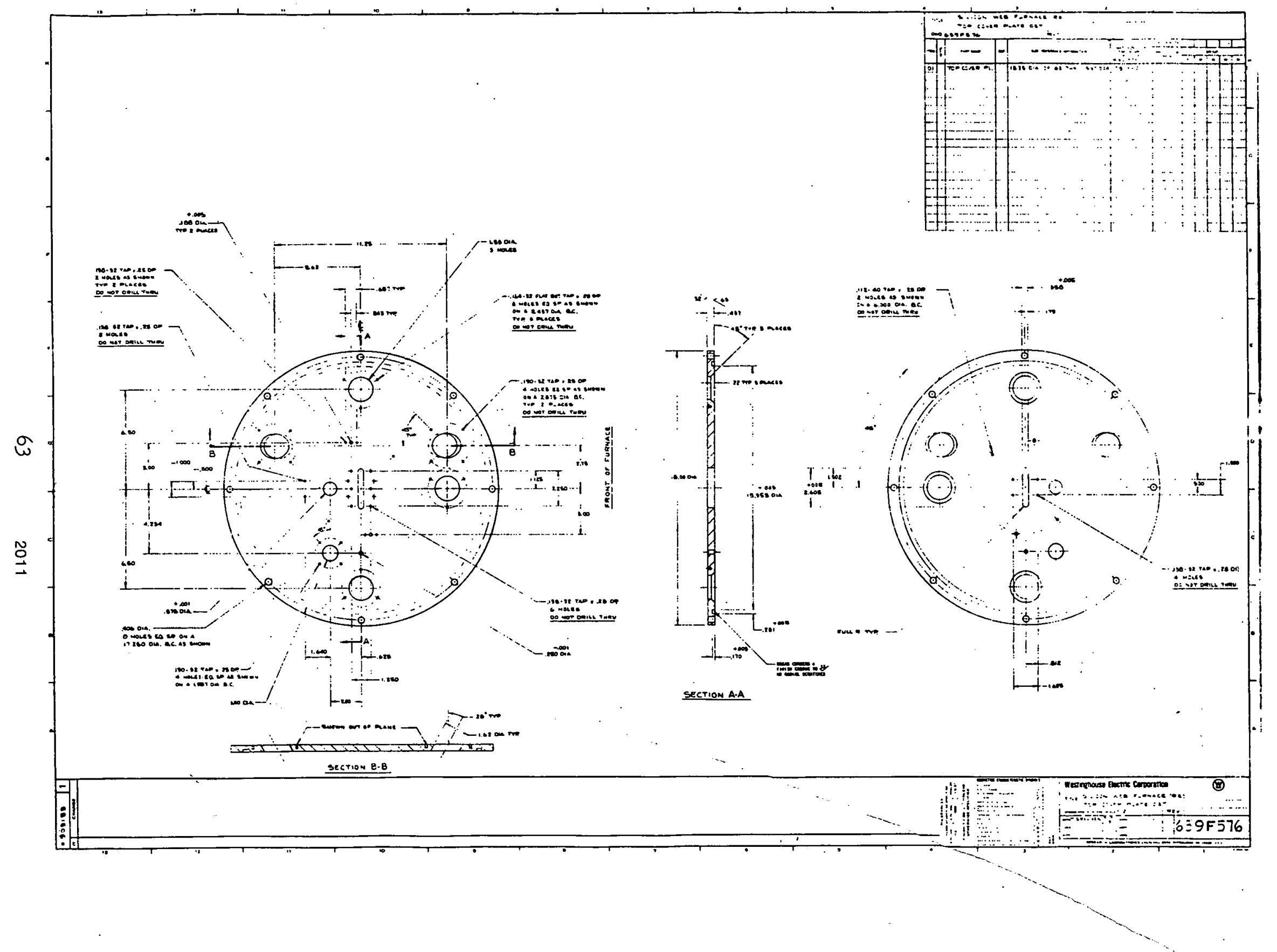




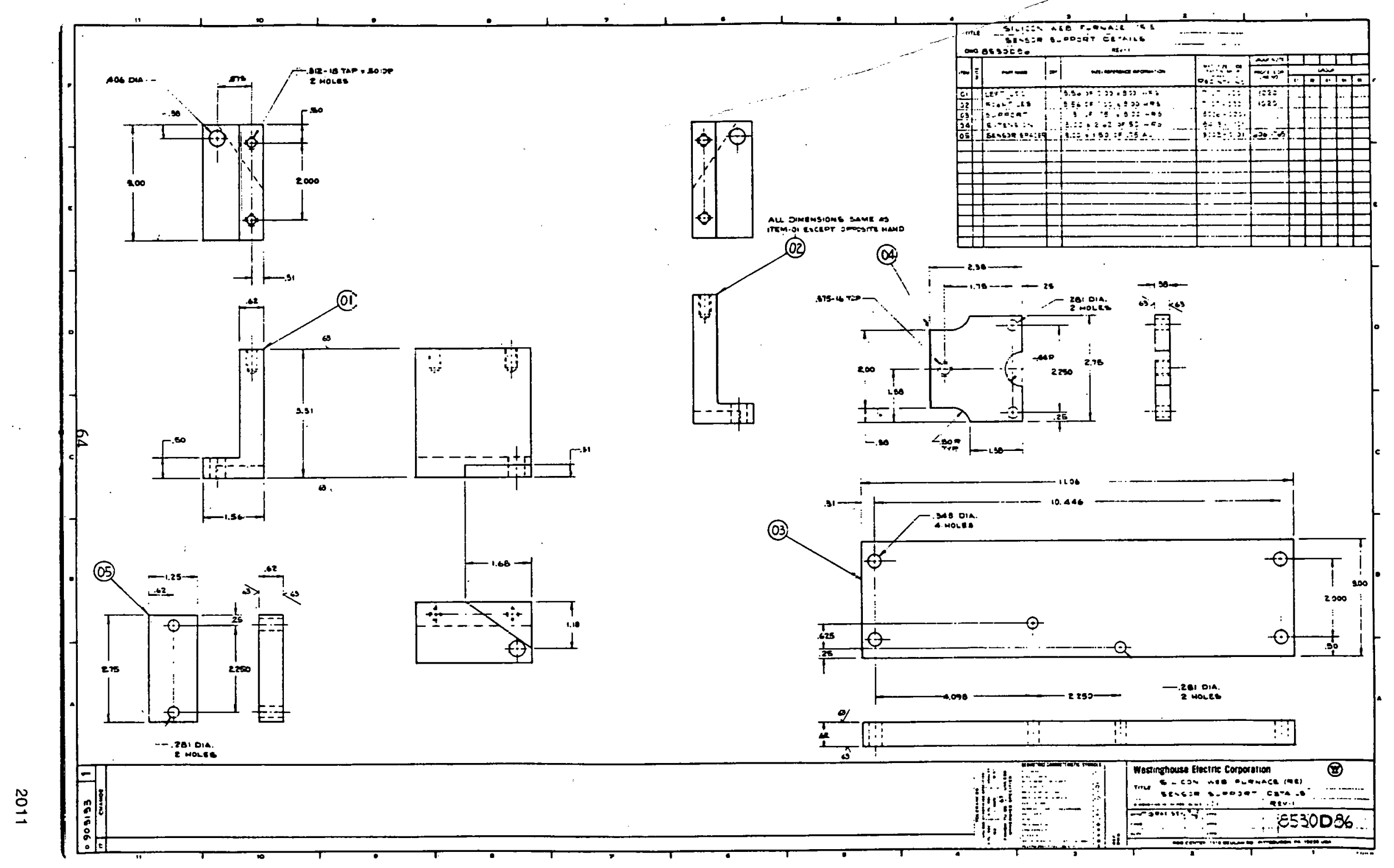




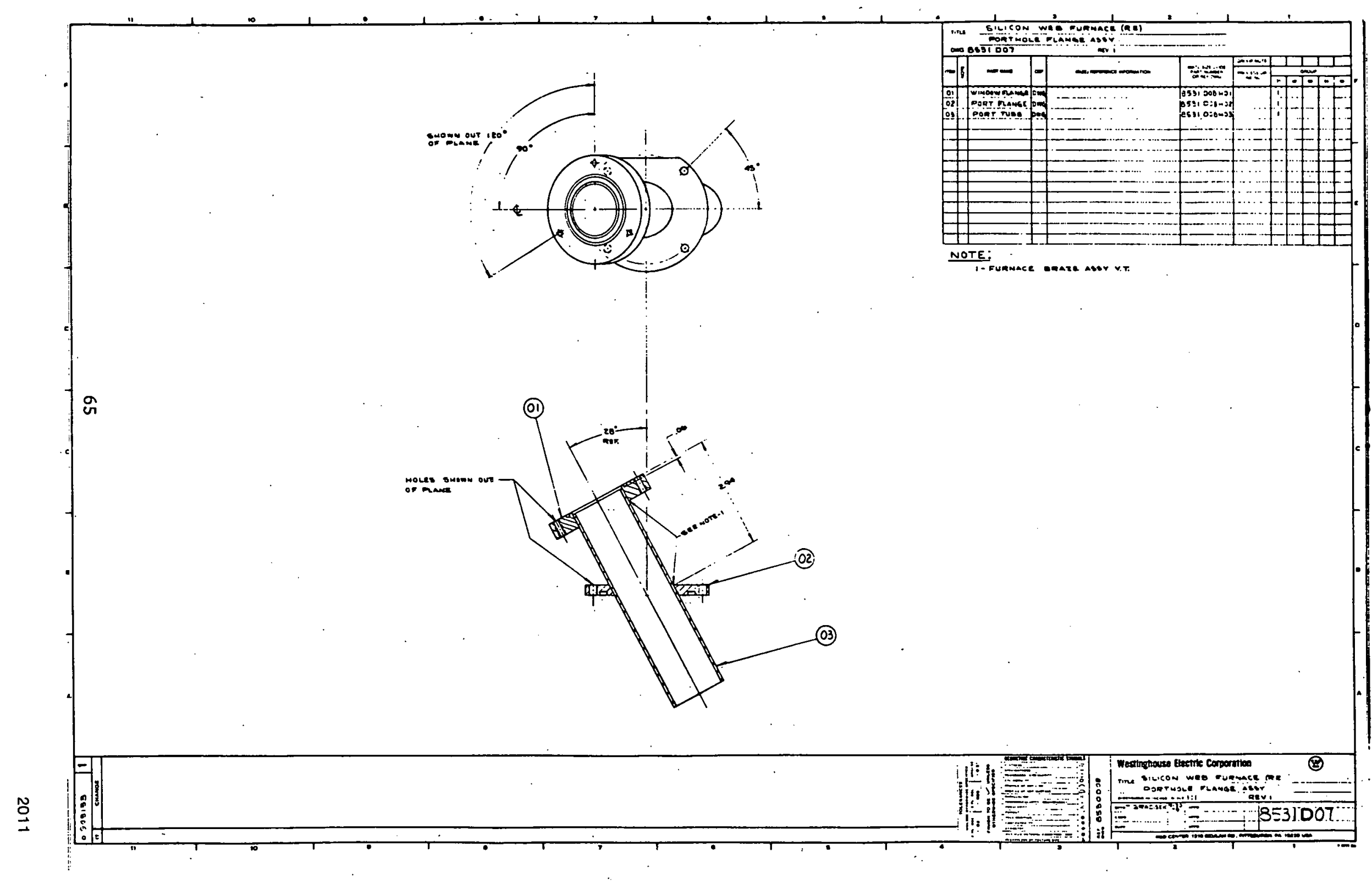




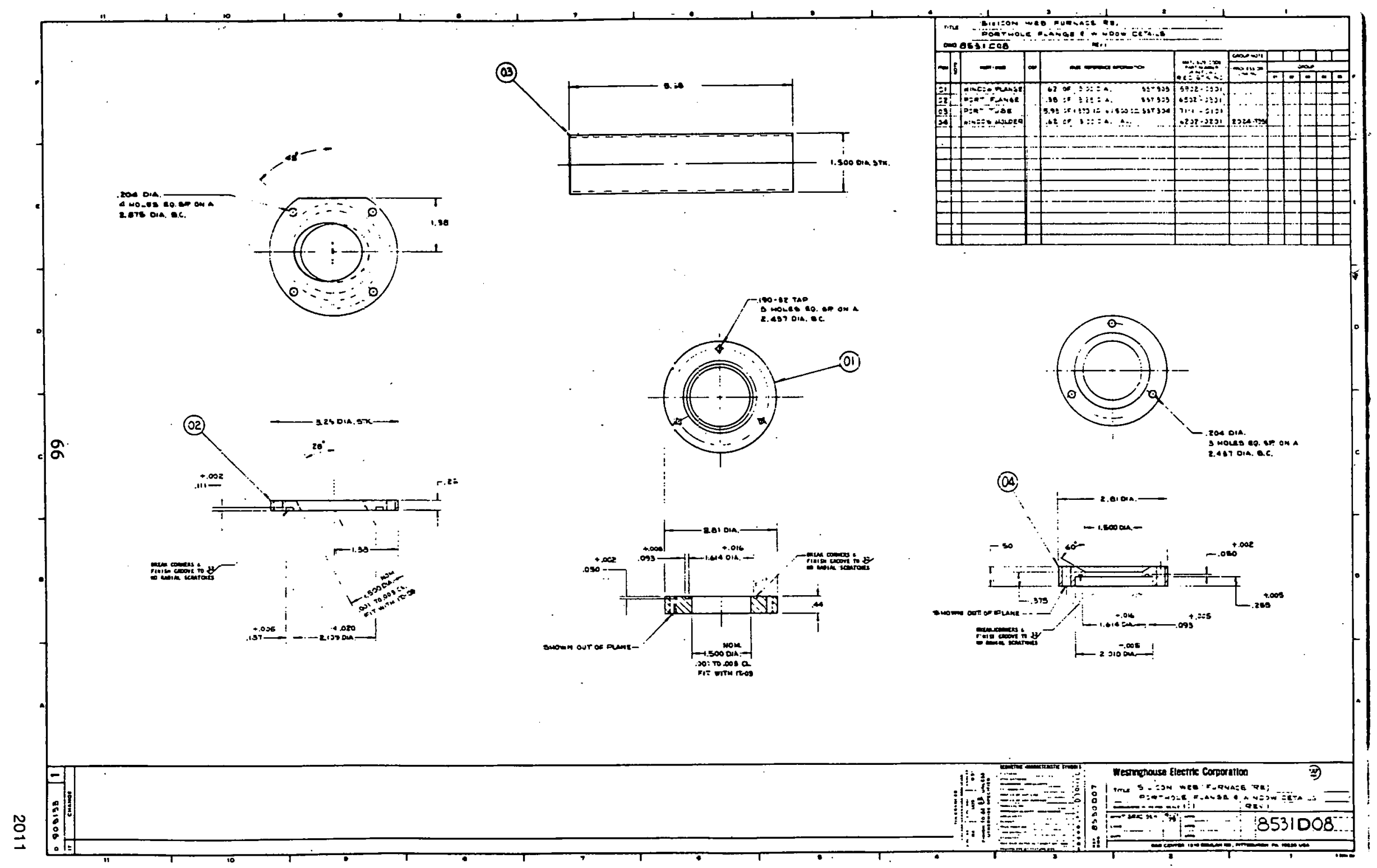




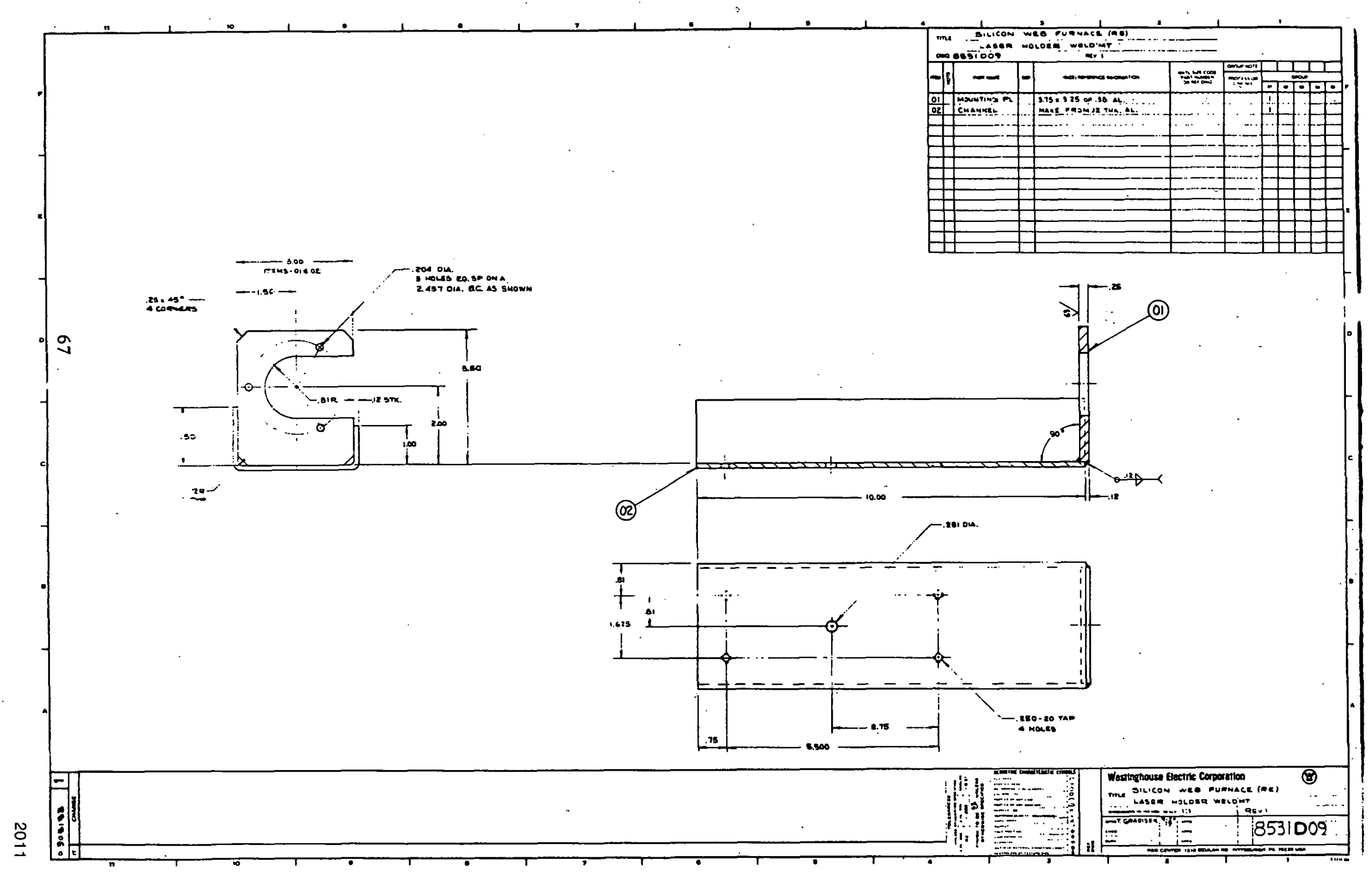




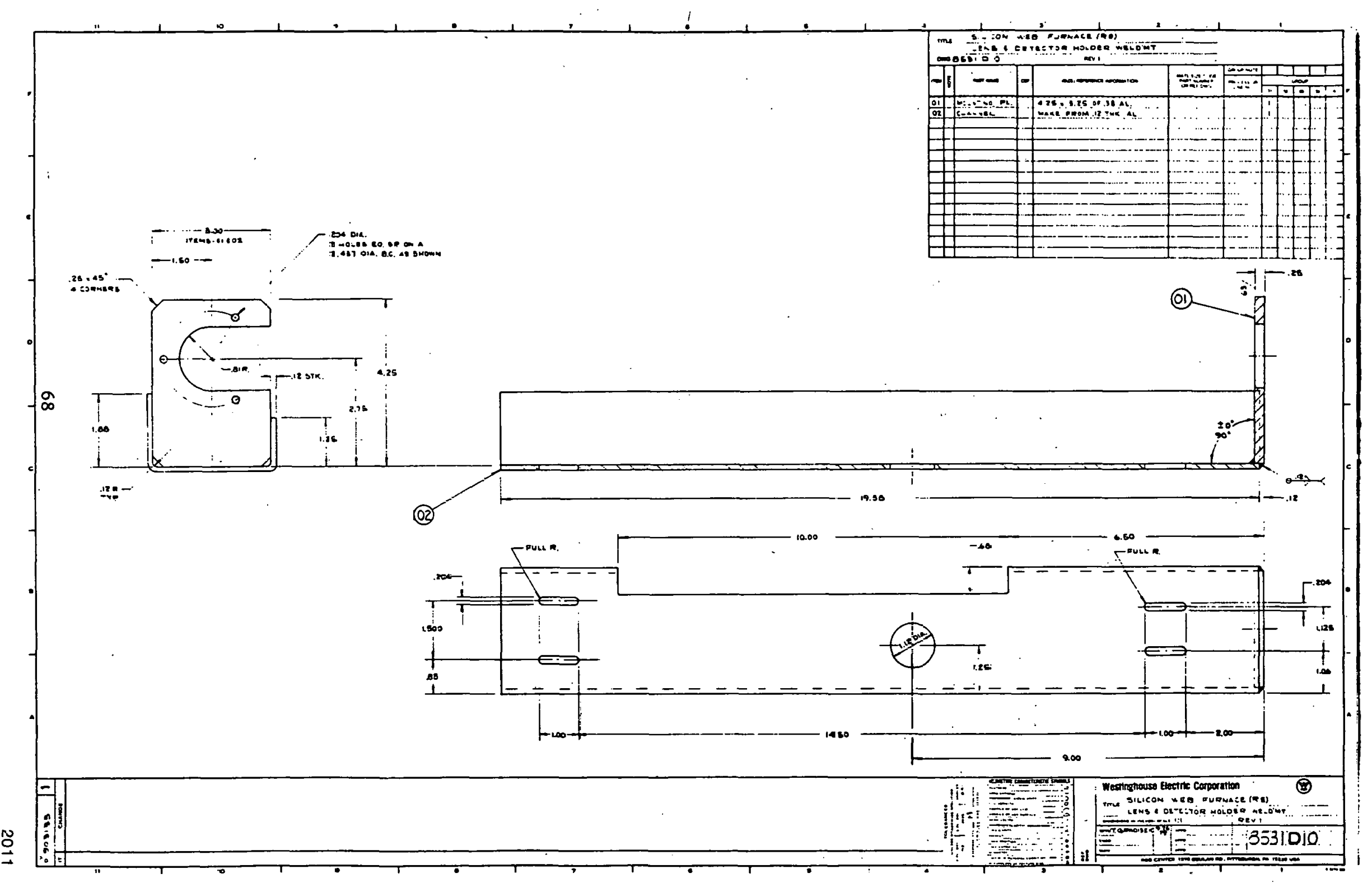




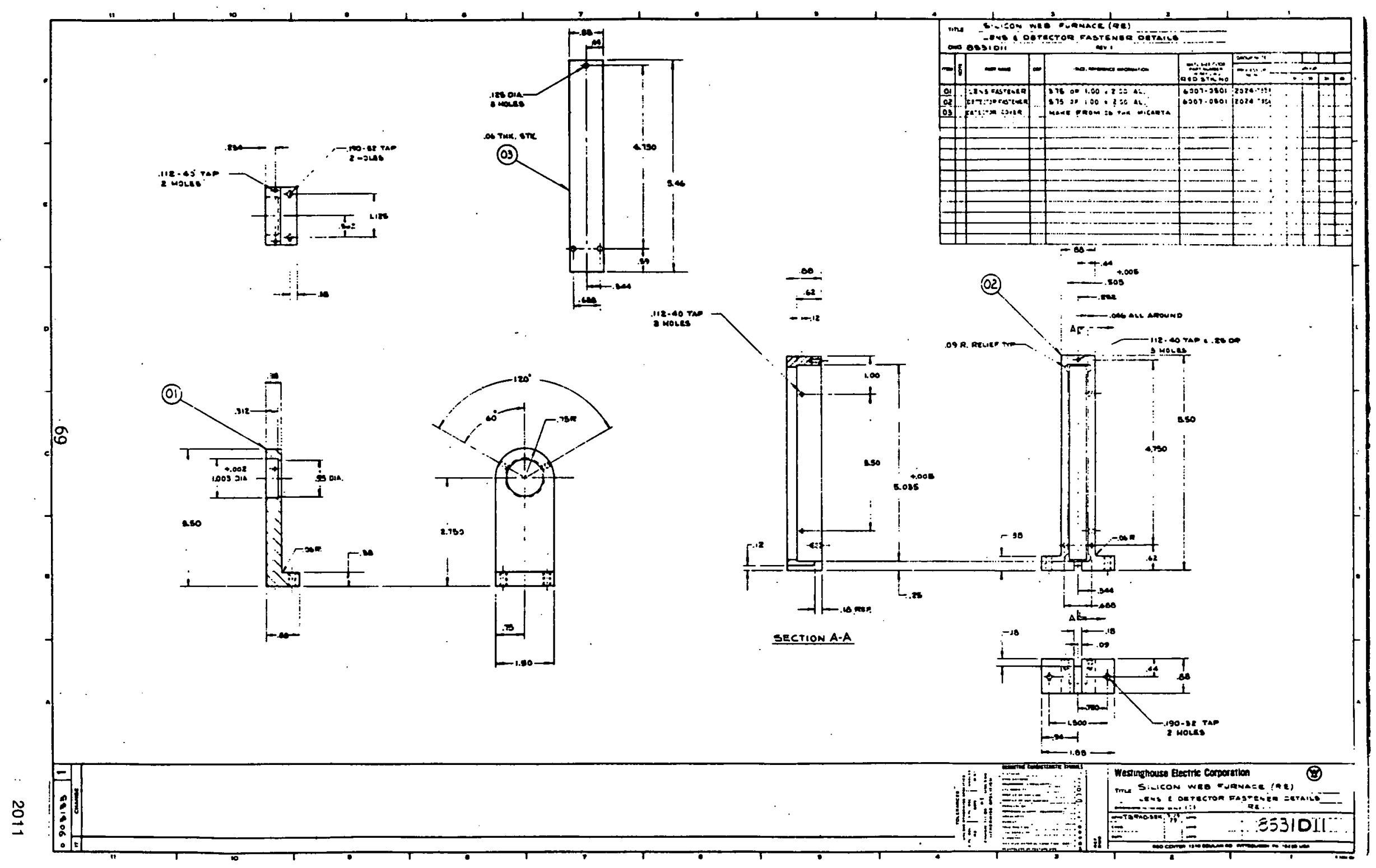




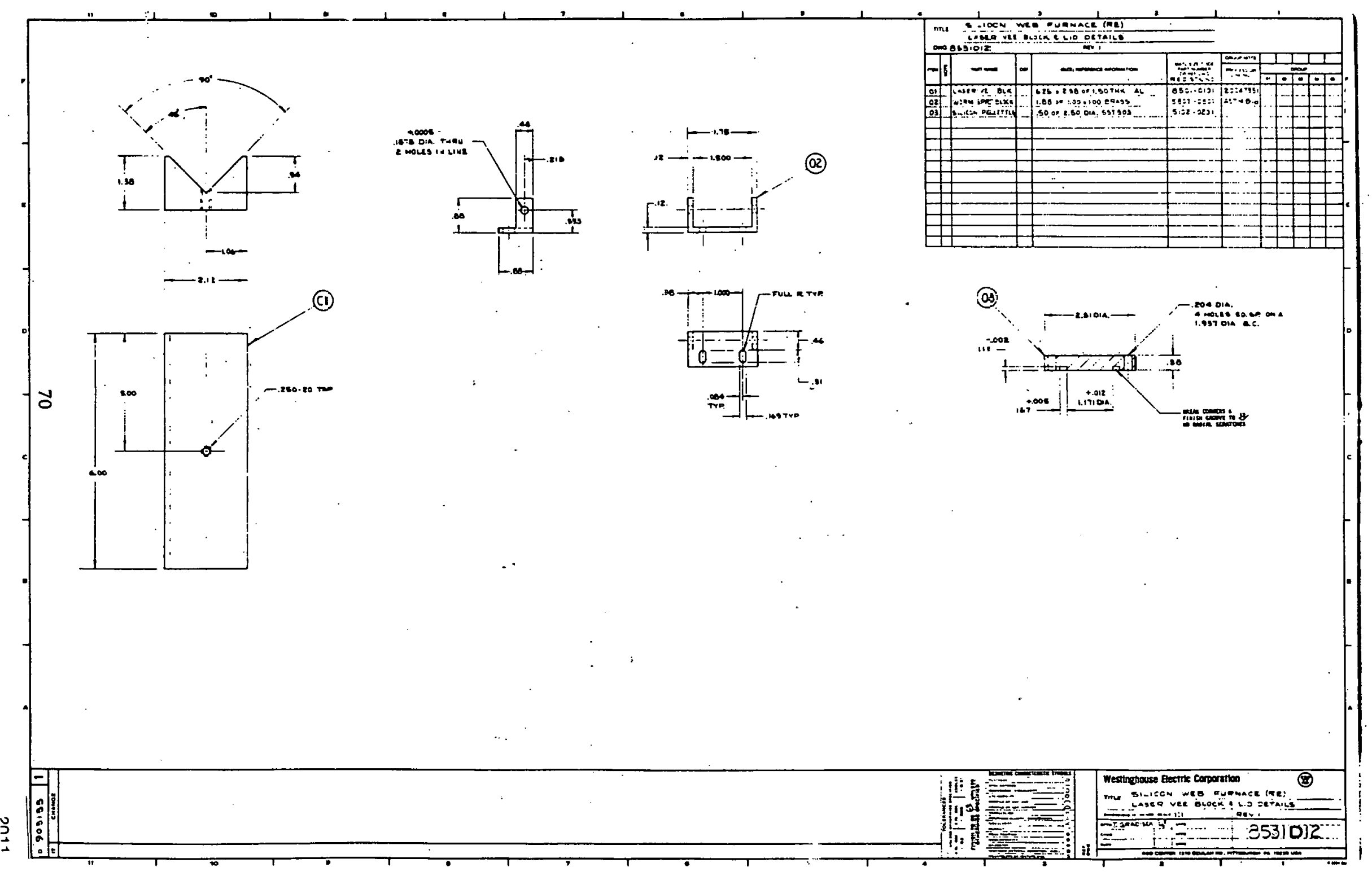




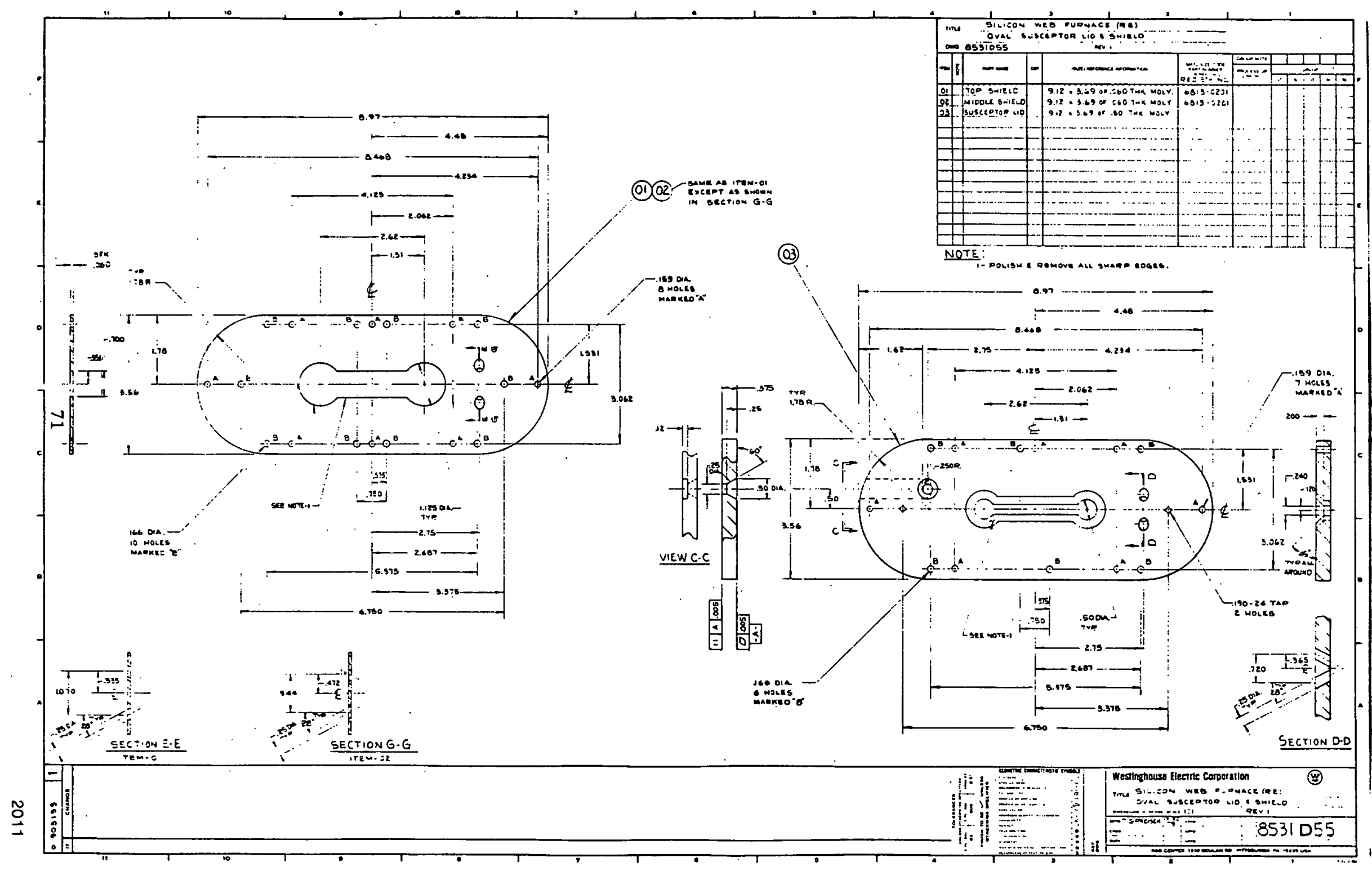




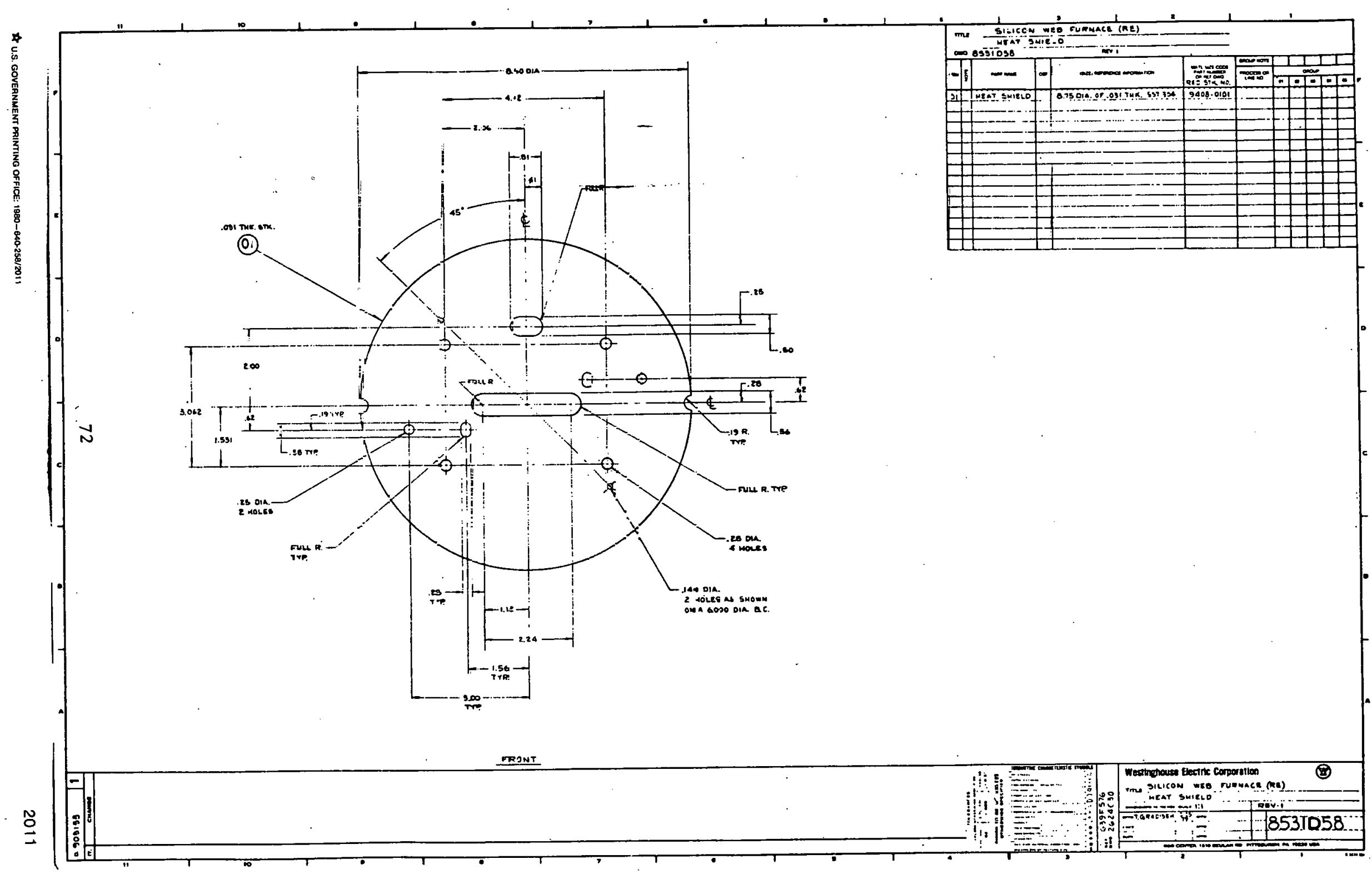

